Prepared in cooperation with the

State of Nevada Department of Conservation and Natural Resources

Division of Environmental Protection

\title{
Water-Table Levels and Gradients, Nevada, 1947-2004
}

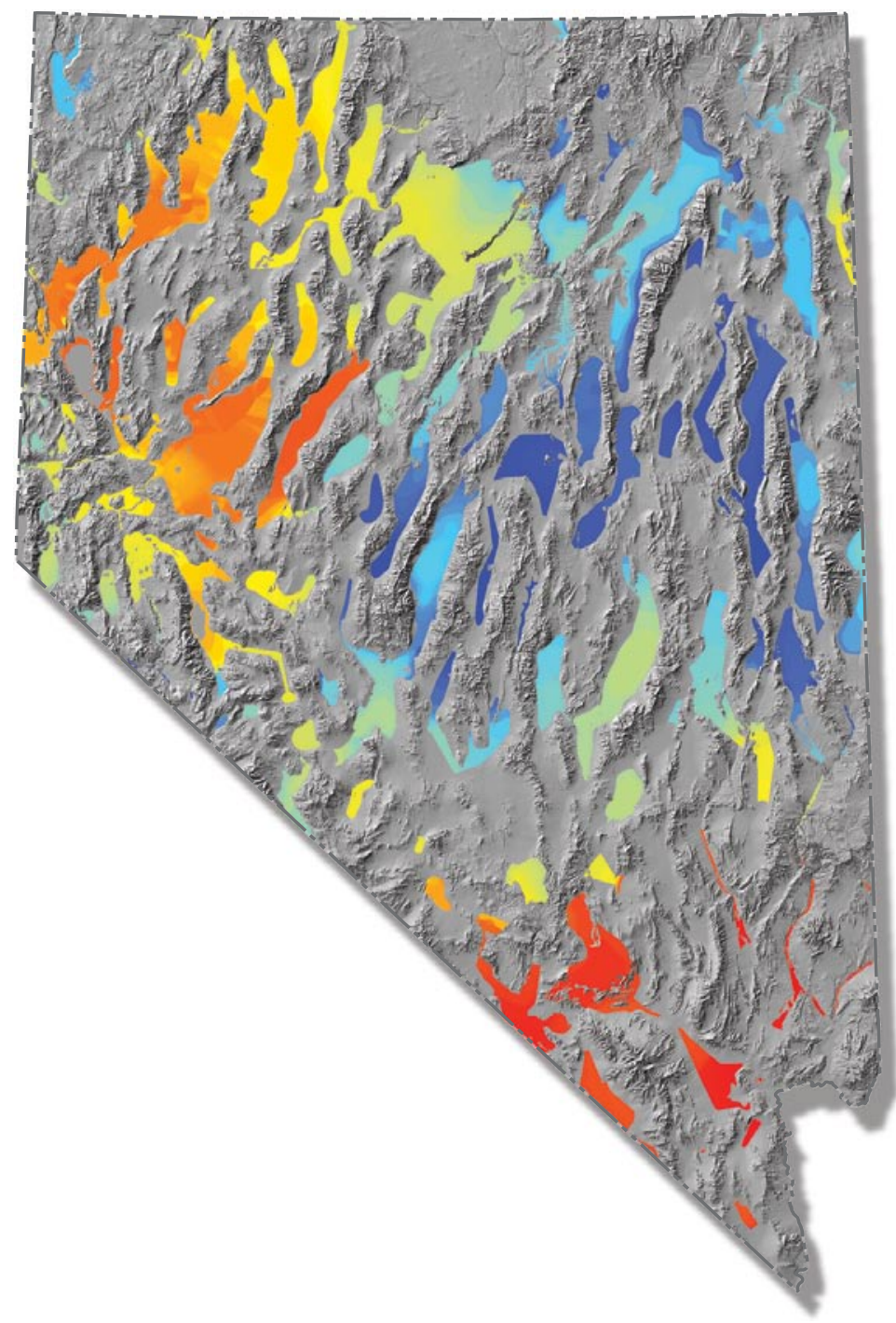

Scientific Investigations Report 2006-5100

U.S. Department of the Interior

U.S. Geological Survey 
FRONT COVER: Water-table surfaces in Nevada, 1947-2004. 


\section{Water-Table Levels and Gradients, Nevada, 1947-2004}

By Thomas J. Lopes, Susan G. Buto, J. LaRue Smith, and Toby L. Welborn

Scientific Investigations Report 2006-5100

Prepared in cooperation with the State of Nevada Department of Conservation and Natural Resources

Division of Environmental Protection

U.S. Department of the Interior

U.S. Geological Survey 


\section{U.S. Department of the Interior \\ Dirk Kempthorne, Secretary}

\section{U.S. Geological Survey \\ P. Patrick Leahy, Acting Director}

Use of trade, product, or firm names in this report is for identification purposes only and does not constitute endorsement by the U.S. Geological Survey.

Carson City, Nevada, 2006

For additional information write to:

U.S. Geological Survey

Director, USGS Nevada Water Science Center

2730 N. Deer Run Road

Carson City, NV 89701

Email: GS-W-NVpublic-info@usgs.gov

URL: http://nevada.usgs.gov/

For more information about the USGS and its products:

Telephone: 1-888-ASK-USGS

World Wide Web: http://www.usgs.gov/

Although this report is in the public domain, permission must be secured from the individual copyright owners to reproduce any copyrighted materials contained within this report.

Scientific Investigations Report 2006-5100 


\section{Contents}

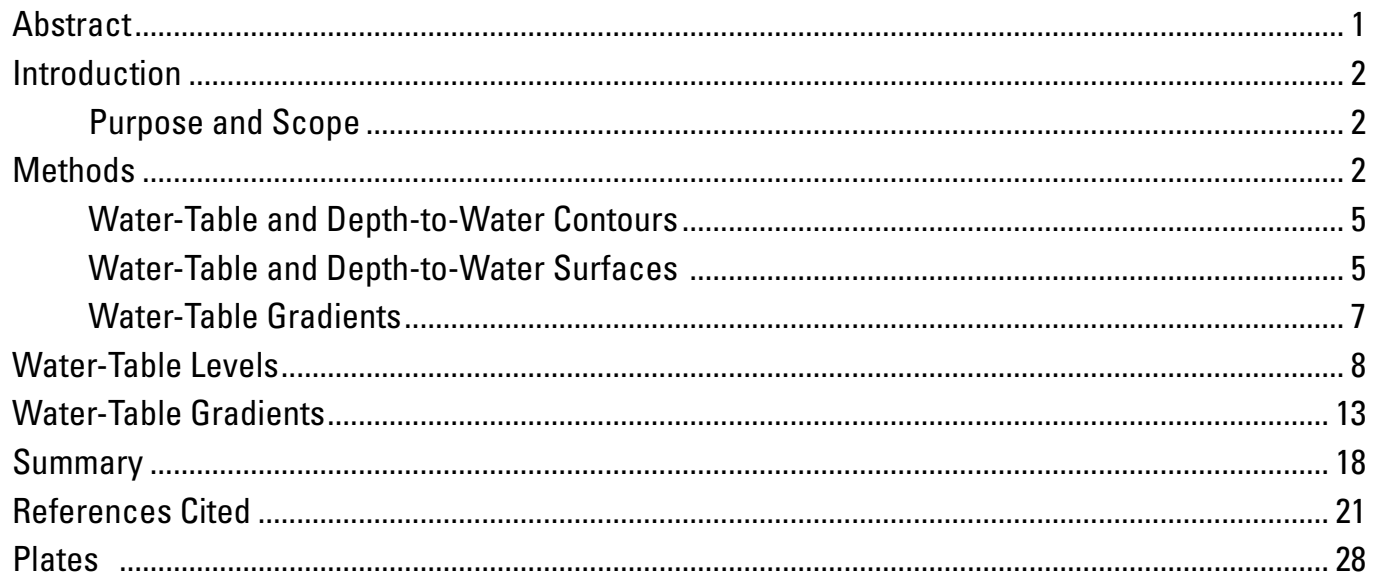

\section{Figures}

Figure 1. Hydrographic areas and locations of wells used to evaluate the accuracy of depth-towater surfaces in Nevada. .3

Figure 2. Depth to water in spring 2001 in the Diamond Valley hydrographic area (153), Nevada...... 6

Figure 3. Differences in depth to water estimated from depth-to-water surface and water-table surfaces versus depth to water estimated from depth-to-water surfaces. ........................... 7

Figure 4. Sites where water-table gradients were characterized. ....................................................... 9

Figure 5. Variables measured at water-table-gradient sites............................................................... 10

Figure 6. Depth to water estimated from depth-to-water surface versus measured depth to

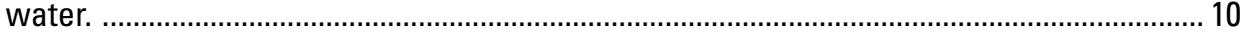

Figure 7. Depth-to-water surfaces and areas of predominantly greasewood.................................... 14

Figure 8. Ground-water discharge areas, areas of predominantly greasewood, and depth-towater less than 100 feet. ................................................................................................... 15

Figure 9. Differences between last and first depth-to-water measurements versus $\mathbf{A}$, well depth, B, years between measurements, and C, first depth-to-water measurement. ....... 16

Figure 10. Differences between last and first depth-to-water measurements grouped by hydrographic-area number

Figure 11. Ranges in water-table gradients $\mathbf{A}$, beneath alluvial fans and valley floors and $\mathbf{B}$, grouped by adjacent consolidated-rock hydrogeologic unit..

Figure 12. Water-table gradients in unconsolidated sediments versus $\boldsymbol{A}$, horizontal hydraulic conductivity of adjacent consolidated hydrogeologic unit, $\boldsymbol{B}$, upgradient precipitation, and $\boldsymbol{C}$, distance to consolidated-rock contact.

Figure 13. Water-table and land-surface altitude versus distance from the well at the lowest land-surface altitude in Kyle Canyon, Pine Nut Creek, and Vicee Canyon. 


\section{Tables}

Table 1. Scoring system for selecting published water-table and depth-to-water contours used to determine water-table levels in Nevada ................................................................ 5

Table 2. Information used to characterize water-table gradients in Nevada ..................................... 11

Table 3. Water-table measurements for Vicee Canyon, Pine Nut Creek, and Kyle Canyon, Nevada.

\section{Appendix}

Appendix 1. Reports with water-level contours for Nevada. 24

\section{Plates}

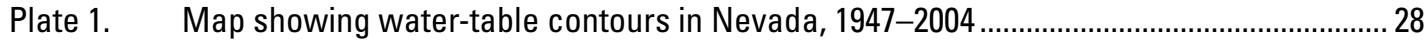

Plate 2. Map showing water-table surfaces in Nevada, 1947-2004 ................................................ 28

Plate 3. Map showing depth-to-water surfaces in Nevada, 1947-2004 ............................................. 28

\section{Conversion Factors and Datums}

\begin{tabular}{rrl}
\hline \multicolumn{1}{c}{ Multiply } & \multicolumn{1}{c}{ By } & \multicolumn{1}{c}{ To obtain } \\
\hline foot (ft) & 0.3048 & meter \\
mile (mi) & 1.609 & kilometer \\
square mile (mi $\left.{ }^{2}\right)$ & 2.590 & square kilometer \\
foot per day (ft/d) & 0.3048 & meter per day \\
acre-foot per year (acre-ft/yr) & 1,233 & cubic meter per year \\
\hline
\end{tabular}

Datums

Vertical coordinate information is referenced to the National Geodetic Vertical Datum of 1929; horizontal coordinate information is referenced to the North American Datum of 1927 (NAD 27). 


\title{
Water-Table Levels and Gradients, Nevada, 1947-2004
}

\author{
By Thomas J. Lopes, Susan G. Buto, J. LaRue Smith, and Toby L. Welborn
}

\section{Abstract}

In 1999, the U.S. Environmental Protection Agency began a program to protect the quality of ground water in areas other than ground-water protection areas. These other sensitive ground water areas (OSGWA) are areas that are not currently, but could eventually be, used as a source of drinking water. The OSGWA program specifically addresses existing wells that are used for underground injection of motor-vehicle waste. To help determine whether a well is in an OSGWA, the Nevada Division of Environmental Protection needs statewide information on depth to water and the water table, which partly control the susceptibility of ground water to contamination and contaminant transport. This report describes a study that used available maps and data to create statewide maps of water-table and depth-to-water contours and surfaces, assessed temporal changes in water-table levels, and characterized water-table gradients in selected areas of Nevada.

A literature search of published water-table and depthto-water contours produced maps of varying detail and scope in 104 reports published from 1948 to 2004 . Where multiple maps covered the same area, criteria were used to select the most recent, detailed maps that covered the largest area and had plotted control points. These selection criteria resulted in water-table and depth-to-water contours that are based on data collected from 1947 to 2004 being selected from 39 reports. If not already available digitally, contours and control points were digitized from selected maps, entered into a geographic information system, and combined to make a statewide map of water-table contours. Water-table surfaces were made by using inverse-distance weighting to estimate the water table between contours and then gridding the estimates. Depth-to-water surfaces were made by subtracting the water-table altitude from the land-surface altitude.

Water-table and depth-to-water surfaces were made for only 21 percent of Nevada because of a lack of information for 49 of 232 basins and for most consolidated-rock hydrogeologic units. Depth to water is commonly less than 50 feet beneath valley floors, 50 to 500 feet beneath alluvial fans, and more than 500 feet in some areas such as north-central and southern Nevada. In areas without water-table information, greasewood and mapped ground-water discharge areas are good indicators of depth to water less than 100 feet. The average difference between measured depth to water and depth to water estimated from surfaces was 90 feet. More recent and detailed information may be needed than that presented in this report to evaluate a specific site.

Temporal changes in water-table levels were evaluated for 1,981 wells with 10 or more years between the first depth-to-water measurement and last measurement made since 1990. The greatest increases in depth to water occurred where the first measurement was less than 200 feet, where the time between first and last measurements was 40 years or less, and for wells between 100 and 600 feet deep. These characteristics describe production wells where ground water is fairly shallow in recently developing areas such as the Las Vegas and Reno metropolitan areas. In basins with little pumping, 90 percent of the changes during the past 100 years are within \pm 20 feet, which is about the natural variation in the water table due to changes in the climate and recharge.

Gradients in unconsolidated sediments of the Great Basin are generally steep near mountain fronts, shallow beneath valley floors, and depend on variables such as the horizontal hydraulic conductivity of adjacent consolidated rocks and recharge. Gradients beneath alluvial fans and valley floors at 58 sites were correlated with selected variables to identify those variables that are statistically related. Water-table measurements at three sites were used to characterize the water table between the valley floor and consolidated rock.

Water-table gradients beneath alluvial fans had a median of 0.02 , a mean of 0.04 , and a standard deviation of 0.05 . Gradients beneath valley floors had a median of 0.005 , a mean of 0.03 , and a standard deviation of 0.07. Information from this and other reports suggest that the average linear velocity of ground water is roughly 10 times faster beneath alluvial fans than beneath valley floors. Contaminants may travel about 10 times faster beneath alluvial fans than beneath valley floors, depending on the physical and chemical properties of the aquifer material and contaminant.

Gradients in unconsolidated sediments adjacent to different consolidated rocks differed significantly (p-value less than or equal to 0.05 ), which could be related to the horizontal hydraulic conductivity of the consolidated rocks and the sediments derived from them. Spearman rank correlations were statistically significant between gradients and the horizontal hydraulic conductivity of adjacent consolidated-rock hydrogeologic units (-0.30), precipitation up-gradient of the site (0.32), distance to the alluvial-fan contact (-0.31), and distance to the consolidated-rock contact (-0.41). These relations are consistent with the general description of the water table along mountain fronts and with precipitation being the driving force for gradients. 
An examination of water tables at three sites suggests it may be possible to estimate the water table where data are sparse. Kyle Canyon, in Las Vegas Valley, has few domestic wells compared to Pine Nut Creek, in Carson Valley. Vicee Canyon, in Eagle Valley, has two production wells and is the most developed of the three sites. The initial water tables at Vicee Canyon and Kyle Canyon had similar shapes and were nearly parallel to land-surface altitude. Linear regression of water-table altitude with land-surface altitude from both sites had a slope of 0.89 and an r-squared of 0.97 . If this relation is valid for other hydrogeologic settings, then water-table levels in undeveloped areas could be estimated from a few measurements. Recent (2000-2004) water tables at Pine Nut Creek and Vicee Canyon are similar and are not parallel with land-surface altitude, suggesting that pumping has changed the linear relation. At Vicee Canyon, pumping has reversed the gradient so that ground water flows from the valley floor toward the mountain front. The non-linear relation would depend on the amount of pumpage, making it difficult to estimate watertable levels in developed areas. This study used existing data to characterize gradients. A study specifically designed to characterize gradients may result in stronger correlations that could be used to estimate gradients and the water table where few data exist.

\section{Introduction}

In 1999, the U.S. Environmental Protection Agency began a program to protect the quality of ground water in areas other than ground-water protection areas (U.S. Environmental Protection Agency, 2000). Ground-water protection areas surrounding currently used production wells, are protected under the wellhead and source-water protection programs, and constitute a small percentage of Nevada. Other sensitive groundwater areas (OSGWA) are large areas that are not currently, but could eventually be, used as a source of drinking water and are protected under the OSGWA program. OSGWAs do not include areas that could not be used as a source of drinking water, such as saline ground water near playas. The OSGWA program specifically addresses existing wells that are used for underground injection of motor vehicle waste; new injection wells are banned. If an injection well is in a ground-water protection area or an OSGWA, well owners must either close the well or apply for a permit. A permit is granted only if the injectate fluids meet drinking-water standards.

Nevada is a large, rural, and hydrologically complex state that lies almost entirely within the Great Basin physiographic province (fig. 1). Sparse data throughout much of Nevada makes it difficult to determine which aquifers could be sensitive to contamination. Rather than designate specific areas as an OSGWA, the Nevada Division of Environmental Protection (NDEP) will evaluate site-specific information associated with the permit application and determine if the aquifer at the site is sensitive (Nevada Division of Environmental Protection,
2003). To evaluate permit applications, NDEP needs statewide information on depth to water, altitude of the water table, and other variables that control the susceptibility of ground water to contamination and contaminant transport. The greater the depth to water, the greater the probability that contaminants will degrade or sorb to sediments before reaching ground water, which makes shallow aquifers generally more sensitive to contamination than deep aquifers. If the contaminant reaches ground water, water-table altitude is needed to determine the direction and rate of ground-water flow and to identify water supplies that could be affected.

The U.S. Geological Survey (USGS), in cooperation with NDEP, started a study in 2001 to compile information on variables that could control aquifer susceptibility and vulnerability and to estimate the potential for ground-water degradation from anthropogenic contamination. As part of the study, the USGS used available, published water-table and depth-towater contours and other data to determine statewide watertable levels and water-table gradients. This report presents the water-table levels and gradients and is one of four reports from this study. Maurer and others (2004) describe the hydrogeology of Nevada and areas with similar horizontal hydraulic conductivity, soil permeability, precipitation, slope, and aspect. Lopes and Evetts (2004) estimated ground-water pumpage and artificial recharge for the year 2000 and compiled estimates of average annual natural recharge and interbasin flow by hydrographic area. Lopes (2006) described methods and results of evaluating the quality of Nevada's aquifers and their susceptibility to contamination.

\section{Purpose and Scope}

The purpose of this report is to present (1) statewide maps of water-table contours and water-table and depth-towater surfaces, and (2) water-table gradients determined from water-level measurements. The report includes an assessment of temporal changes in water-table levels, an assessment of the variables that affect gradients in unconsolidated sediments, and general estimates of ground-water velocity. Published maps and data from 1947-2004 were used in the study. Potentiometric surfaces of confined aquifers were not included.

\section{Methods}

Water-table and depth-to-water contours were compiled from published reports and were used to make digital surfaces of interpolated water-table levels. Recent data were used to make previously unpublished contours for Buffalo and Diamond Valleys. Recent and historical data were used to evaluate temporal changes and characterize the water table between the valley floor and consolidated rock. Water table and gradients in different hydrogeologic settings were characterized using field measurements, site characteristics, and graphical and 


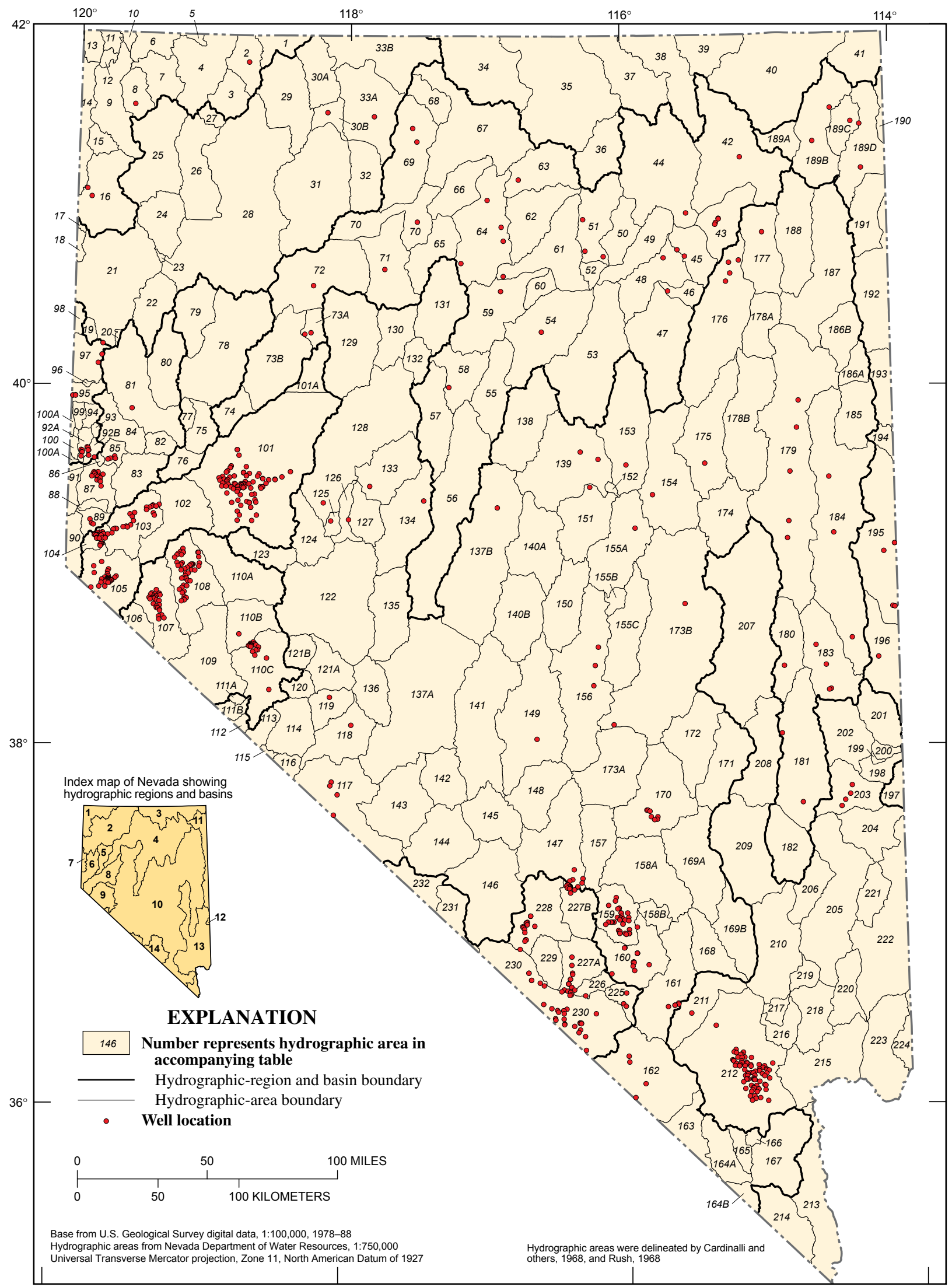

Figure 1. Hydrographic areas and locations of wells used to evaluate the accuracy of depth-to-water surfaces in Nevada. 
STATE OF NEVADA--HYDROGRAPHIC AREAS

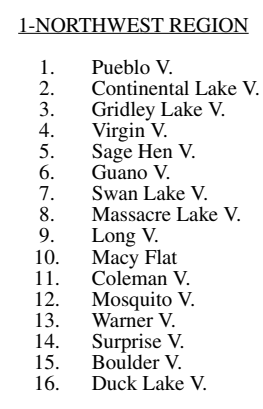

\section{2-BLACK ROCK DESERT REGION}

$\begin{array}{ll}\text { 17. } & \text { Pilgrim Flat } \\ 18 . & \text { Painter Flat } \\ \text { 19. } & \text { Dry V. } \\ 20 . & \text { Sano V. } \\ 21 . & \text { Smoke Creek Desert } \\ 22 . & \text { San Emidio Desert } \\ 23 . & \text { Granite Basin } \\ 24 . & \text { Hualapai Flat } \\ 25 . & \text { High Rock Lake V. } \\ 26 . & \text { Mud Meadow } \\ 27 . & \text { Summit Lake V. } \\ 28 . & \text { Black Rock Desert } \\ 29 . & \text { Pine Forest V. } \\ 30 . & \text { Kings River V. } \\ & \text { (A) Rio King Subarea } \\ 31 . & \text { Desert Sod House Subarea } \\ 32 . & \text { Silver State V. } \\ 33 . & \text { Quinn River V. } \\ & \text { (A) Orovada Subarea } \\ & \text { (B) McDermitt Subarea } \\ & \end{array}$

\section{3-SNAKE RIVER BASIN}

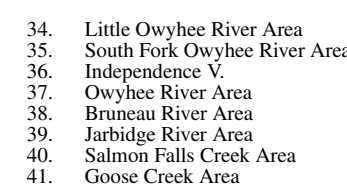

\section{4-HUMBOLDT RIVER BASIN}

\begin{tabular}{ll} 
42. & Marys River Area \\
43. & Starr V. Area \\
44. & North Fork Area \\
45. & Lamoille V. \\
46. & South Fork Area \\
\hline 47. & Huntington V.
\end{tabular}

South Fork Area

Huntington V.

Dixie Creek --

Elko Segment

Susie Creek Area
Maggie Creek Area

Marys Creek Area

Pine V.

Crescent V.

Carico Lake V.
Upper Reese River V.

Antelope V.

Middle Reese River V.

Lower Reese River V.

Whirlwind V.

Boulder Flat

Rock Creek V.

Willow Creek V.

Clovers Area
Pumpernickel V.

Pumpernickel V.
Kelly Creek Area

Kelly Creek Area
Little Humboldt V.

Hardscrabble Area

Hardscrabble
Paradise V.

Winnemucca Segment

71. Grass V.

(A) Oreana Subarea

74. White Plains

\section{5-WEST CENTRAL REGION

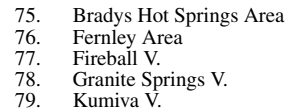

6-TRUCKEE RIVER BASIN

$\begin{array}{ll}\text { 80. } & \text { Winnemucca Lake V. } \\ \text { 81. } & \text { Pyramid Lake V. } \\ \text { 82. } & \text { Dodge Flat } \\ \text { 83. } & \text { Tracy Segment } \\ \text { 84. } & \text { Warm Springs V. }\end{array}$
85. Spanish Springs V.

86. Sun V.

87. Truckee Meadows

88. Pleasant V.

89. Washoe V.
90. Lake Tahoe Basin

90. Lake Tahoe Basin
91. Truckee Canyon Segment

7-WESTERN REGION

92. Lemmon $\mathrm{V}$.

(A) Western Part
(B) Eastern Part

93. Antelope V.

95. Bedell

95. Nry V.

97. Honey Lake V.
98. Skedaddle Creek V.

99. Red Rock V.

100. Cold Spring V.

(A) Long V.
(ald Spring V.

8-CARSON RIVER BASIN

$$
\begin{aligned}
& \text { 101. Carson Desert } \\
& \text { (A) Packard V. } \\
& \text { 102. Churchill V. } \\
& \text { 103. Dayton V. } \\
& \text { 104. Eagle V. }
\end{aligned}
$$

105. Carson Valley

\section{9-WALKER RIVER BASIN}

106. Antelope V.
107. Smith V.

108. Mason V.

109. East Walker Area

10. Walker Lake V.

(A) Schurz Subarea

(B) Lake Subarea

C) Whisky Flat --
Hawthorne Subarea

\section{0-CENTRAL REGION}

111. Alkali V. (Mineral).
(A) Northern Part
(B) Southern Part

112. Mono V.

114. Teels Marsh V.

115. Adobe V.

115. Adobe V.

117. Queen V.

118. Columbus Salt Marsh V.

119. Rhodes Salt Marsh V.

120. Garfield Flat

121. Soda Spring V.

(A) Eastern Part

22. Gabbs V.

123. Rawhide Flats

124. Fairview V.

25. Stingaree V.

126. Cowkick V.

27. Eastgate V.

129. Buena Vista V.

131. Buffalo $V$.

132. Jersey V.

133. Edwards Creek V.

134. Smith Cre

135. Ione V.

136. Monte Cristo V.

Big Smoky V.
(A) Tonopah Flat

(B) Northern Part

138. Grass V.

139. Kobeh V.

(A) Northern Part

41. Ralston V.

141. Ralston V.

142. Alkali Sping

143. Clayton V.

144. Lida V.

146. Sarcobatus Flat

147. Gold Flat

148. Cactus Flat

149. Stone Cabin V.
150. Little Fish Lake V.

151. Antelope V. (Eureka \& Nye)

152. Stevens Basin

153. Diamond V.

154. Newark V.

155. Little Smoky V. (A) Northern Part (C) Southern Part

156. Hot Creek V.

157. Kawich V.

(A) Groom Lake V.
(B) Papoos Lek
159. Yucca Flat

160. Frenchman Flat

161. Indian Springs V.

162. Pahrump V.

163. Mesquite V. (Sandy V.)

164. Ivanpah V.

(A) Northern Part

(B) Southern Part

165. Jean Lake V.

166. Hidden V. (South)

167. Eldorado $\mathrm{V}$

168. Three Lakes V. (Northern Part)

Tikapoo V. (Tickaboo V.)

(A) Northern Par

170. Penoyer V. (Sand Spring V.)

171. Coal V.

172. Garden V.

(A) Southern Part

(B) Northern Part

174. Jakes V.

175. Long V.

176. Ruby V.

177. Clover V.

$$
\text { (A) Northern Part (Round V.) }
$$

(B) Southern Part

179. Steptoe V.

180. Cave V.

181. Dry Lake V.

183. Lake V.

185. Tippett $\mathrm{V}$.

186. Antelope V. (White Pine \& Elko)

(A) Southern Part

187. Goshute V.

188. Independence V. (Pequop V.)

11-GREAT SALT LAKE BASIN

189. Thousand Springs V

(A) Herrill Siding--Brush Creek Area

(B) Toano--Rock Spring Area

(C) Rocky Butte Area

Montello--Crittenden Creek Area

190. Grouse Creek V.)

190. Grouse Creek

192. Great Salt Lake Desert

193. Deep Creek V.

194. Pleasant $\mathrm{V}$.

195. Snake V.

12-ESCALANTE DESERT

197. Escalante Desert

13-COLORADO RIVER BASIN

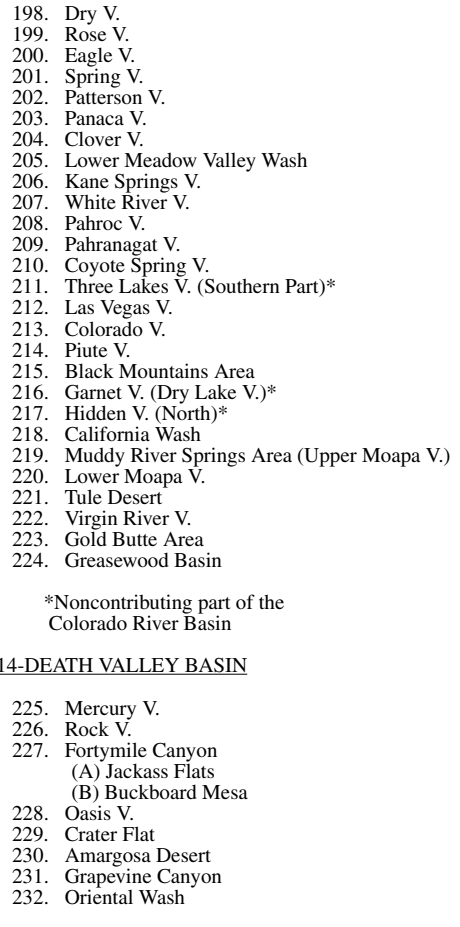

Figure 1. Hydrographic areas and locations of wells used to evaluate the accuracy of depth-to-water surfaces in Nevada-Continued. 
statistical techniques (Helsel and Hirsch, 1992). Statistical results were considered significant at a p-value of less than or equal to 0.05 .

\section{Water-Table and Depth-to-Water Contours}

A literature search of published water-table and depthto-water contours for Nevada produced 104 reports with maps of varying detail and scope published from 1948 to 2004 (appendix 1). Twenty-eight maps had depth-to-water contours and 90 maps had water-table contours. Two maps cover most of Nevada (Rush, 1974; Bedinger and others, 1984). However, these maps lack detail and were used only if no other information was available.

Each map was reviewed to determine which hydrographic areas (HAs) were covered. Cardinalli and others (1968) and Rush (1968) delineated 232 HAs for Nevada, based generally on drainage-area divides (fig. 1; Peltz and others, 2005). HAs are different than hydrologic units (National Atlas of the United States, 1998) and are used by the State for scientific and administrative purposes.

If multiple maps covered the same HA, a scoring system was used to determine which map to use in the study (table 1). The scoring system was designed such that the highest scores were for the most recent, most detailed maps that covered the largest area and had plotted control points. The score for each map was the sum of points for each of four criteria: percentage of hydrographic area contoured, contour interval, date of water-level measurements, and plotting of control points. Maps with the highest score were chosen for this study. Plotted control points had less weight than other criteria and were not a deciding factor because about 85 percent of the maps had plotted points. In cases where multiple maps had the same score, maps that covered multiple HAs were chosen so that contours would be consistent over as large an area as possible. Through this process, water-table contours were selected from 38 of the reports and were based on data collected from 1947 to 2004 (appendix 1). The only contours available for Honey Lake Valley (HA 97) are simulated water-table contours (Handman and others, 1990). Contours were simulated with a computer model that was calibrated to within $5 \mathrm{ft}$ of the measured water-table level. Depth-to-water contours from Rush

Table 1. Scoring system for selecting published water-table and depth-to-water contours used to determine water-table levels in Nevada

[Abbreviations: $<$, less than; > greater than; $\geq$, greater than or equal to $; \leq$, less than or equal to; - , not applicable]

\begin{tabular}{lccccc}
\hline \multicolumn{1}{c}{ Criterion } & \multicolumn{4}{c}{ Score } \\
\cline { 2 - 5 } & $\mathbf{0}$ & $\mathbf{1}$ & $\mathbf{2}$ & $\mathbf{3}$ \\
\hline Percentage of hydrographic area contoured & - & $<25$ & 25 to $<75$ & $\geq 75$ \\
Contour interval, in feet & - & $>20$ & $>10$ to 20 & $\leq 10$ \\
Date of water-level measurements & - & Pre-1975 & $1975-1989$ & Post-1989 \\
Were control points on map? & No & Yes & - & - \\
\hline
\end{tabular}

(1974) were used to estimate the water table in some HAs, such as the Carson Desert (HA 101).

If not already available digitally, contours and control points were digitized from selected maps, entered into a geographic information system (GIS), and combined with available digital contours and points to make a statewide map of water-table contours (plate 1; data can be accessed at http:// water.usgs.gov/lookup/getspatial?sir2006-5100_wanv_l). For areas with sparse or no published contours, point measurements were retrieved from the USGS National Water Information System (NWIS) database and were plotted.

Water levels measured during spring 1996 were used to make water-table contours in Buffalo Valley (HA 131; plate 1). Water levels measured during spring 2001 were used to make depth-to-water contours in Diamond Valley (HA 153; fig. 2; data can be accessed at http://water.usgs.gov/lookup/ getspatial?sir2006-5100_dtwha153_l). The contours were digitized and entered into the GIS. Diamond Valley has had large amounts of ground-water pumpage for agricultural use since contours were first published by Eakin (1962) (Lopes and Evetts, 2004). Comparison of 1962 contours with 2001 contours indicates that depth to water has increased tens of feet in southern Diamond Valley.

\section{Water-Table and Depth-to-Water Surfaces}

Detailed procedures of making water-table and depth-towater surfaces are described by data can be accessed at http:// water.usgs.gov/lookup/getspatial?sir2006-5100_dtwnv_g and http://water.usgs.gov/lookup/getspatial?sir2006-5100_wanv_ $g$. Briefly, the water table between contours was estimated using inverse-distance weighting. Interpolated estimates were then converted into a gridded surface of 1,000-ft cells. A boundary was drawn around contours to limit the extent of interpolation. Where the hydrogeology, water-table contours, and literature indicated a continuous aquifer system, the boundary was drawn around contours of contiguous HAs to make a single surface. Gradational color shading of the range in water-table altitude was used to show the general direction of ground-water flow (plate 2). The same procedure was used to make a gridded surface of depth to water in HAs for which Rush (1974, data can be accessed at http://water.usgs.gov/ lookup/getspatial?nv_dtw750nv_l) was the only information available. Some HAs, such as Smoke Creek Desert (HA 21), have only a single contour or have a single contour that extends farther than other contours in the HA. For these HAs, either a surface was not made or the extent of the surface was smaller than the extent of the contours in the HA. Therefore, plates should be compared to see what water-table information exists in an HA. 


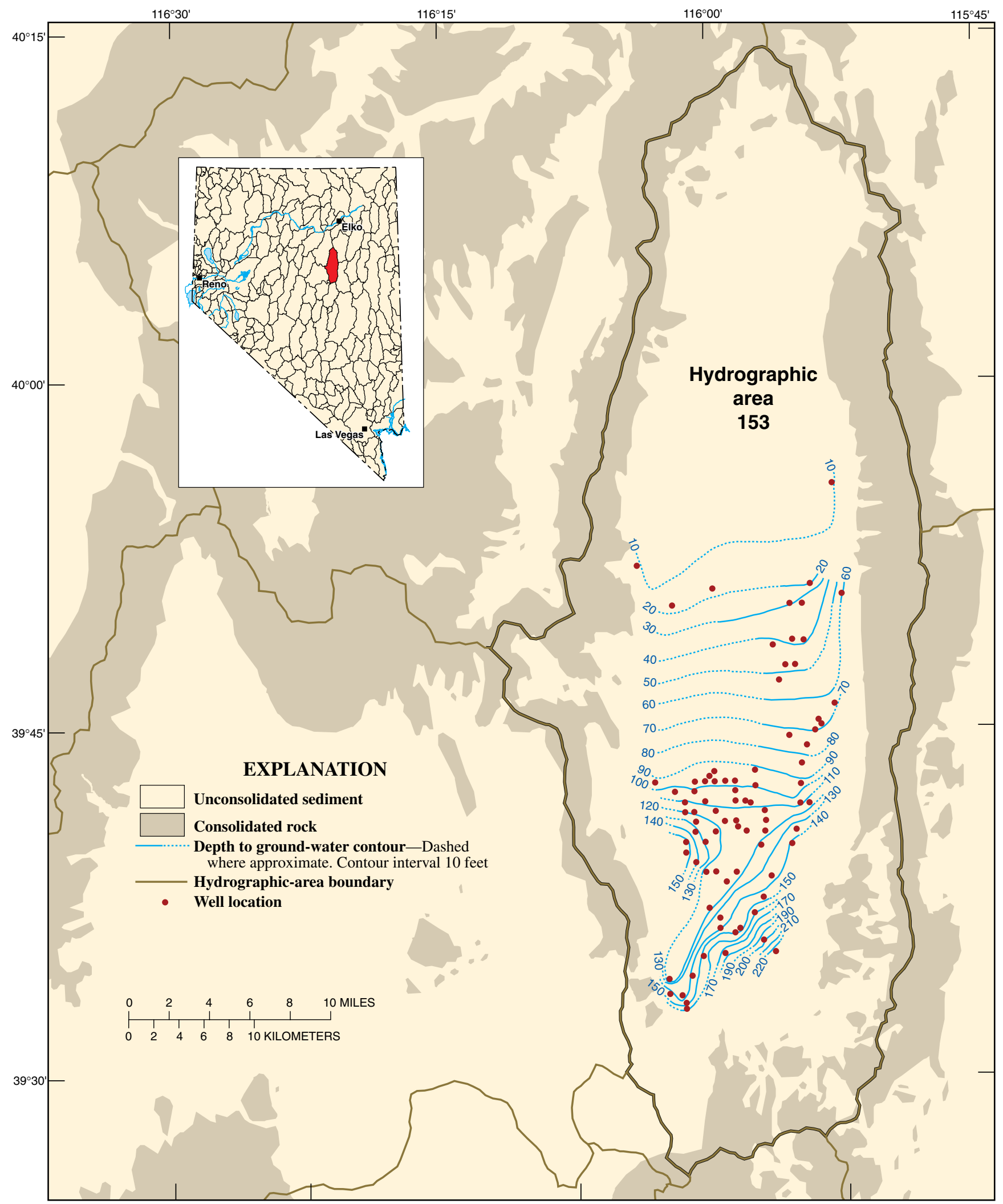

Base from U.S. Geological Survey digital data, 1:100,000, 1978-1988 Universal Transverse Mercator projection, Zone 11, North American Datum of 1927

Figure 2. Depth to water in spring 2001 in the Diamond Valley hydrographic area (153), Nevada. 
Most depth-to-water surfaces were estimated by subtracting the water-table altitude from the National Elevation Dataset (NED; U.S. Geological Survey, 2002) for each cell of the water-table surface (plate 3). For HAs for which Rush (1974) was the only information available, water-table surfaces were estimated by subtracting depth to water from the NED. Depth to water was assumed to be one foot where the difference between the water table and NED resulted in a negative value, which would indicate a water table above land surface. The NED is a digital-raster altitude dataset based primarily on USGS 7.5-minute digital elevation models (DEM). The vertical accuracy depends on the original source DEM, but is about 23 to $49 \mathrm{ft}$ (7 to $15 \mathrm{~m}$; U.S. Geological Survey, 2004). Water-resources agencies and well drillers often want to know the depth to water for a specific area. Thus, depth-to-water surfaces were shown as discrete intervals of color shading rather than gradational color shading.

The accuracy of the method used to estimate depthto-water surfaces described above was evaluated in Mason Valley (HA 108; Huxel and Harris, 1969) and Carson Valley (HA 105; Berger and Medina, 1999), which had both depthto-water and water-table contours. For each valley, gridded depth-to-water surfaces were made from depth-to-water contours and from water-table contours. Differences in depth to water between the two surfaces were calculated for each cell in the grid. The root mean square of differences between the cells was $20 \mathrm{ft}(6 \mathrm{~m})$ for Mason Valley and $15 \mathrm{ft}(4.5 \mathrm{~m})$ for Carson Valley. A paired t-test (Helsel and Hirsch, 1992) was used to determine if depth-to-water surfaces made from water- table contours are different than surfaces made from published depth-to-water contours. The paired t-test indicated that the two depth-to-water surfaces are significantly different for both valleys (p-value $<0.01$; fig. 3 ), but there was no consistent bias. Depth to water estimated from water-table contours was higher than that estimated from depth-to-water contours in Carson Valley and lower in Mason Valley. The largest differences between the surfaces occur near the edges of the valleys, where land-surface altitude changes abruptly. Although there are differences, the procedure produces reasonable estimates of depth to water from water-table contours.

\section{Water-Table Gradients}

The water-table gradient is the slope of the water table and is calculated as the difference in water-table altitude between two points, divided by the distance between the points. Gradients can be estimated from water-table contours (pl. 1) or from water levels measured in two wells screened in the same aquifer. Gradients are necessary to estimate groundwater flow and contaminant transport. The average linear velocity of ground water $\left(q_{x}\right)$ can be estimated using Darcy's Law (equation 1), where $K$ is horizontal hydraulic conductivity, $i$ is gradient, and $n$ is effective porosity (Freeze and Cherry, 1979):

$$
q_{x}=(K \times i) / n
$$

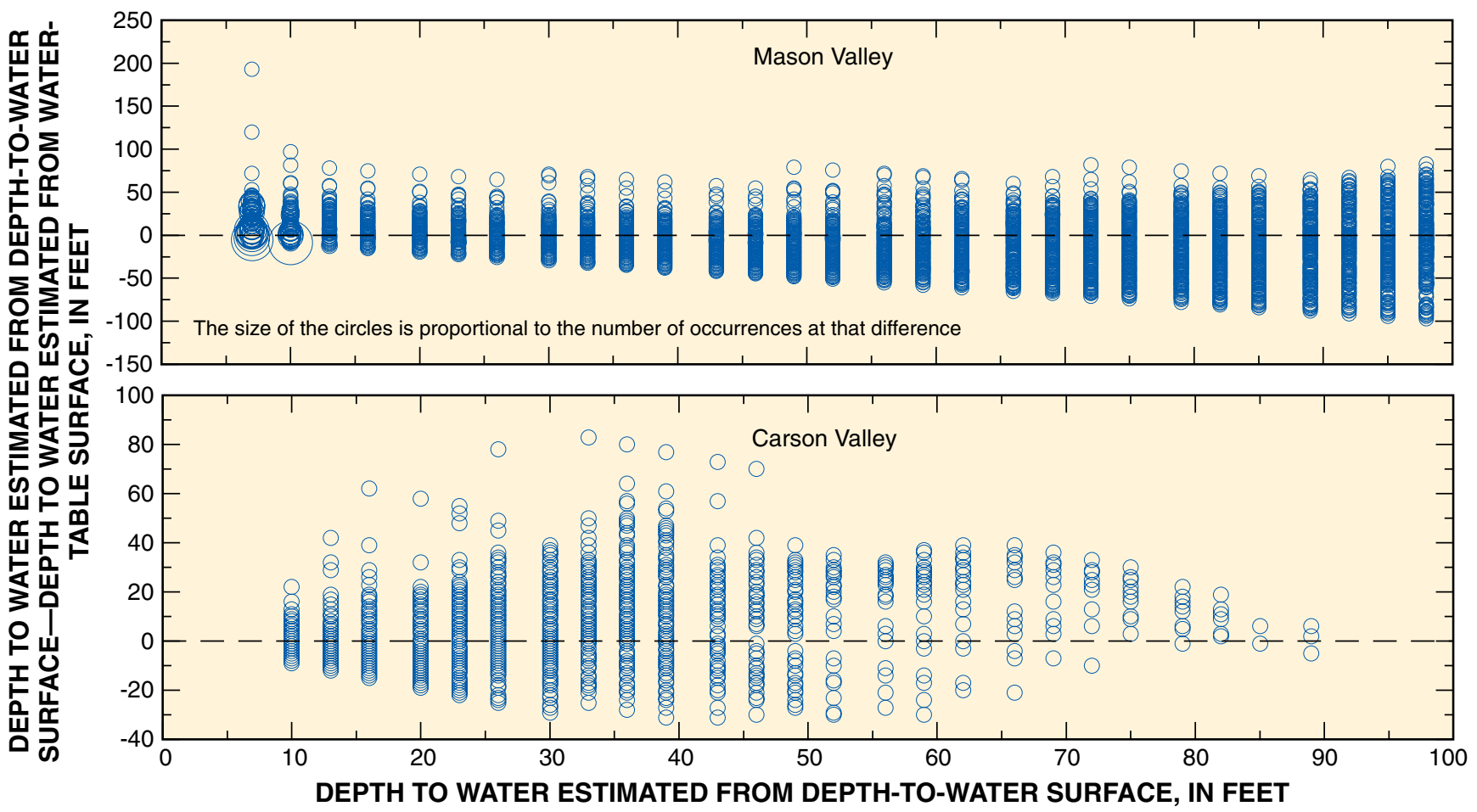

Figure 3. Differences in depth to water estimated from depth-to-water surface and water-table surfaces versus depth to water estimated from depth-to-water surfaces. 
Effective porosity is the interconnected pore volume that contributes to fluid flow. Effective porosity is less than total porosity because it excludes isolated pores. The rate of contaminant transport is estimated by multiplying the average linear velocity by the retardation factor, which depends on the physical and chemical properties of the aquifer material and contaminant (Freeze and Cherry, 1979).

Gradients in unconsolidated sediments of the Great Basin are generally steep near mountain fronts and shallow beneath valley floors (Eakin and others, 1976; Maurer and others, 2004). Variables that could affect gradients in unconsolidated sediments include the source rock and texture of unconsolidated sediments, the amount of recharge and distance from recharge areas, and other variables such as the horizontal hydraulic conductivity of adjacent consolidated rocks. For example, intrusive rocks have a lower horizontal hydraulic conductivity than carbonate rocks and unconsolidated sediments (Maurer and others, 2004). Precipitation could be the same on two mountains, one composed of intrusive rocks and the other composed of carbonate rocks, but gradients in the unconsolidated sediments could be steeper near the intrusive rocks than near the carbonate rocks because of the large contrast in horizontal hydraulic conductivity.

The water table, between the valley floor and consolidated rock, and the variables that could affect the water table has not been well characterized. To identify which variables are most important, the gradient between 58 pairs of wells was correlated with the distance to the alluvial-fan contact, the distance to and horizontal hydraulic conductivity of the adjacent consolidated-rock hydrogeologic unit (Maurer and others, 2004), and precipitation upgradient of the site (Oregon Climate Service, 1997) (figs. 4, 5; table 2). This is a reconnaissance-level characterization of gradients because existing data were used in the analysis. Data in the USGS National Water Information System (NWIS) and either water-table contours or topography were used to select well pairs at the 58 sites that are roughly aligned along ground-water flow directions. However, the wells are at different depths and water levels were measured at different times. The drainage area upgradient of a site could not easily be determined, so it was approximated by a 1-mi-wide area between the site and the HA boundary.

Sixteen of the 58 well pairs are in alluvial fans and 42 are in valley floors, and well pairs are adjacent to most types of consolidated-rock hydrogeologic units in Nevada. Consolidated-rock hydrogeologic units associated with gradients were described by Maurer and others (2004). The two major hydrogeologic units in Nevada are consolidated rocks and unconsolidated sediments, which have different hydrologic properties. Consolidated rocks were subdivided into eight hydrogeologic units. In order of decreasing area covering Nevada, consolidated-rock hydrogeologic units consist of Quaternary to Tertiary age volcanic flows of (1) basaltic; (2) rhyolitic; and (3) andesitic composition; (4) volcanic breccias, tuffs, and volcanic rocks older than Tertiary age; (5) carbonate rocks; (6) Tertiary-age consolidated and semi-consolidated tuffaceous rocks and sediments; (7) clastic rocks consisting of sandstone and siltstone; and (8) intrusive and metamorphic rocks. Unconsolidated sediments were subdivided into (1) alluvial slopes, (2) valley floors, (3) fluvial deposits, and (4) playas.

Water-level measurements and linear regression were used to characterize the water table between the valley floor and consolidated rock at Vicee Canyon in Eagle Valley (HA 104), Pine Nut Creek in Carson Valley (HA 105), and Kyle Canyon in Las Vegas Valley (HA 212) (table 3). Land-surface altitude was measured to within $0.1 \mathrm{ft}$ for wells at Vicee Canyon and Pine Nut Creek and estimated to within 1 to 40 $\mathrm{ft}$ for wells at Kyle Canyon. Kyle Canyon is associated with carbonate rocks and has fewer domestic wells than Pine Nut Creek, which is associated with Tertiary sediments. Vicee Canyon is associated with intrusive rocks, has two production wells, and is the most developed of the three sites. The initial water table prior to large pumping at Vicee Canyon and Kyle Canyon was approximated using the earliest measurements taken on multiple dates. No early water-level data were available for Pine Nut Creek. Measurements used to approximate the water table at Kyle Canyon were made from 1969 to 1990 during September to April when pumping is usually low and prior to most snowmelt. A recent (2004) measurement of a well in Kyle Canyon indicates that water levels have changed little in the area. At Vicee Canyon, water-level measurements made from 1972 to 2002 were used to approximate the initial water table.

\section{Water-Table Levels}

Water-table and depth-to-water surfaces were made for only 21 percent of Nevada because of a lack of information for 49 of 232 HAs and for most consolidated-rock hydrogeologic units (plates 2 and 3). The surfaces represent water-table levels in 40 percent of the unconsolidated sediment and 3 percent of the consolidated-rock hydrogeologic units. Water-table levels exist for the most populated HAs of Las Vegas Valley (HA 212), Truckee Meadows (HA 87), Eagle Valley (HA 104), and Carson Valley (HA 105), although most of these HAs do not have recent information.

The accuracy of the surfaces was evaluated by comparing depth to water measured at 682 wells from January 2000 to March 2004 with depth to water estimated from depth-towater surfaces (figs. 1 and 6). The root mean square of differences between measured and estimated depth to water was 90 $\mathrm{ft}$. To evaluate a specific site, more recent and detailed data may be needed. A paired t-test indicated no significant difference between measured and estimated depth to water ( $\mathrm{p}$-value 0.40 ), thus depth-to-water surfaces do not over- or under-estimate depth to water. The large differences between measured and estimated depth to water could be due to the error of the NED, temporal changes in depth to water due to natural variations and pumping, incorrectly extrapolating contours, or a combination of these explanations. For example, some water- 


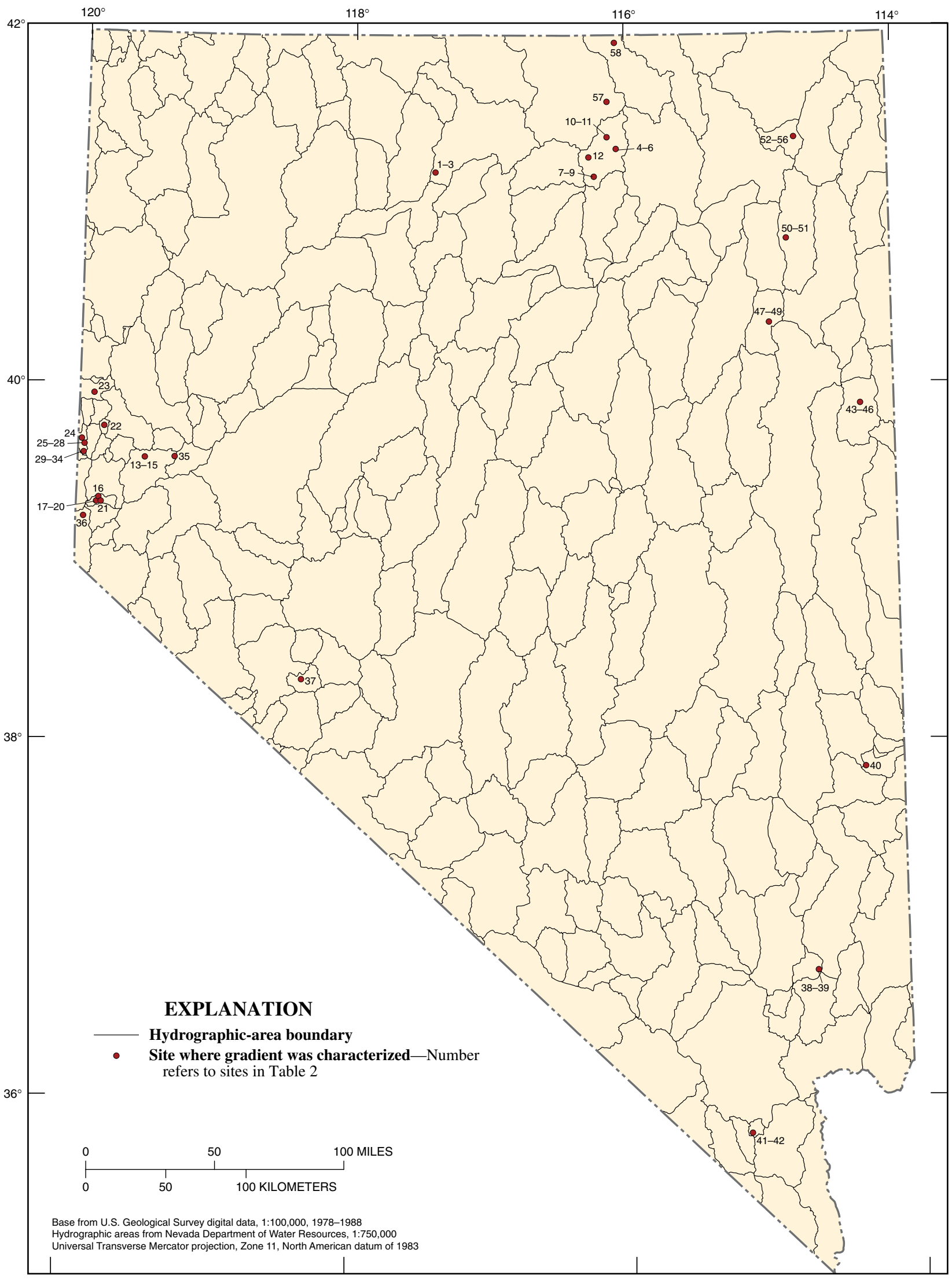

Figure 4. Sites where water-table gradients were characterized. 


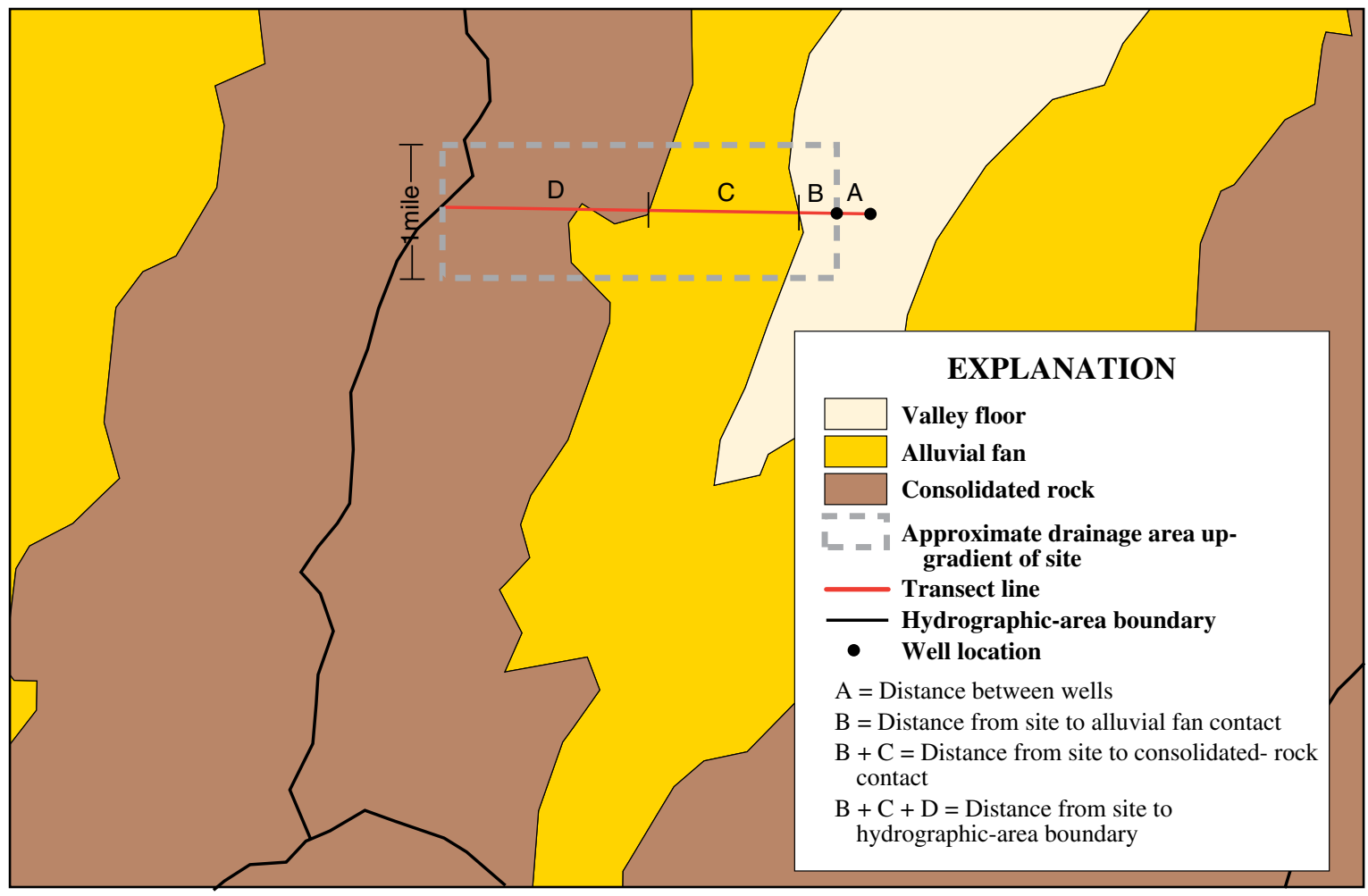

Figure 5. Variables measured at water-table-gradient sites.

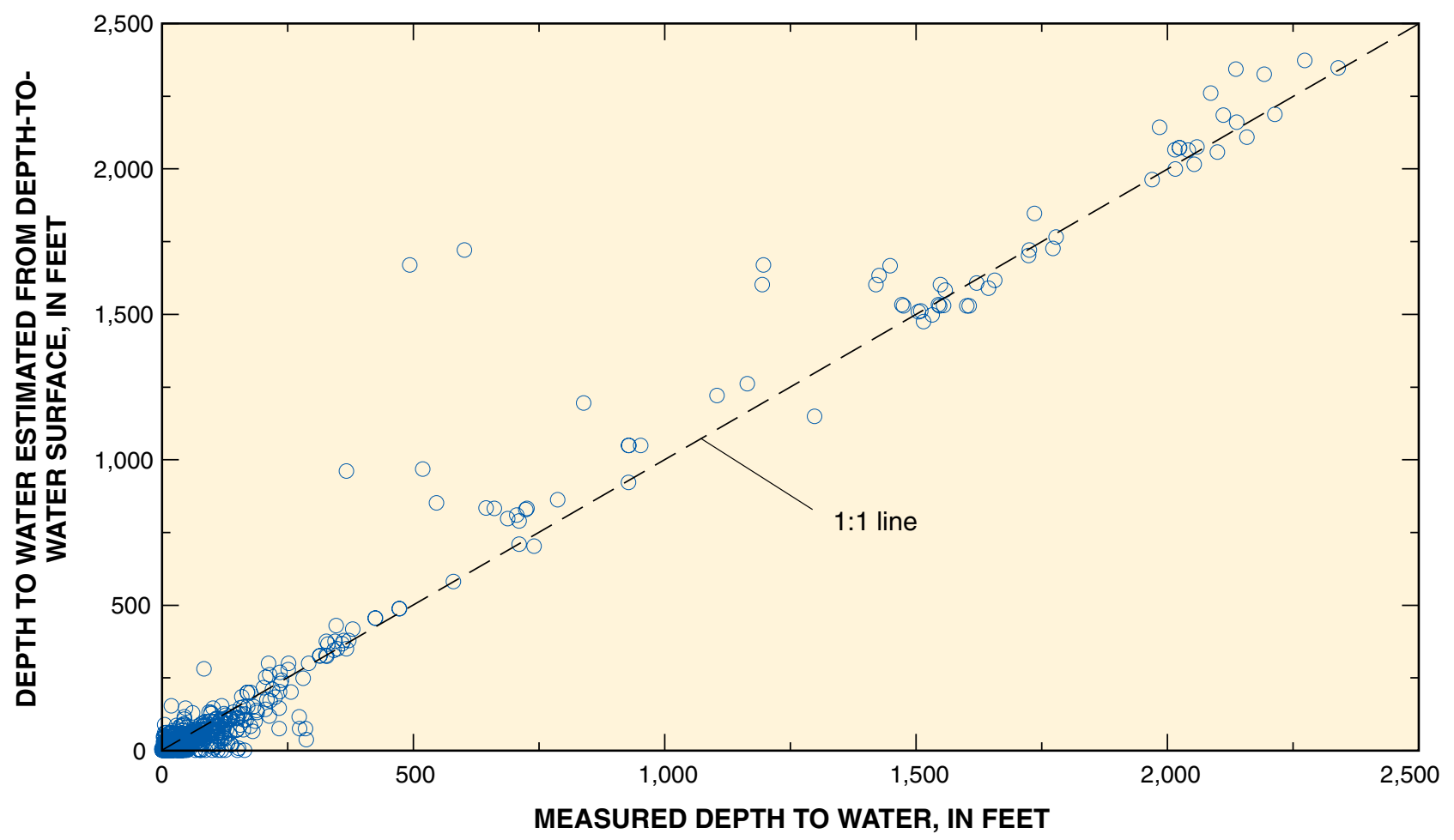

Figure 6. Depth to water estimated from depth-to-water surface versus measured depth to water. 
Table 2. Information used to characterize water-table gradients in Nevada

[Site: Pairs of wells used to characterize gradients; locations shown on figure 4. Adjacent consolidated hydrogeologic unit: BTOV, breccia, tuffs, and older volcanic rocks; TS, tertiary sediments. Hydraulic conductivity: average horizontal hydraulic conductivity of adjacent consolidated hydrogeologic unit. Abbreviations: NGVD, National Geodetic Vertical Datum; - , does not apply]

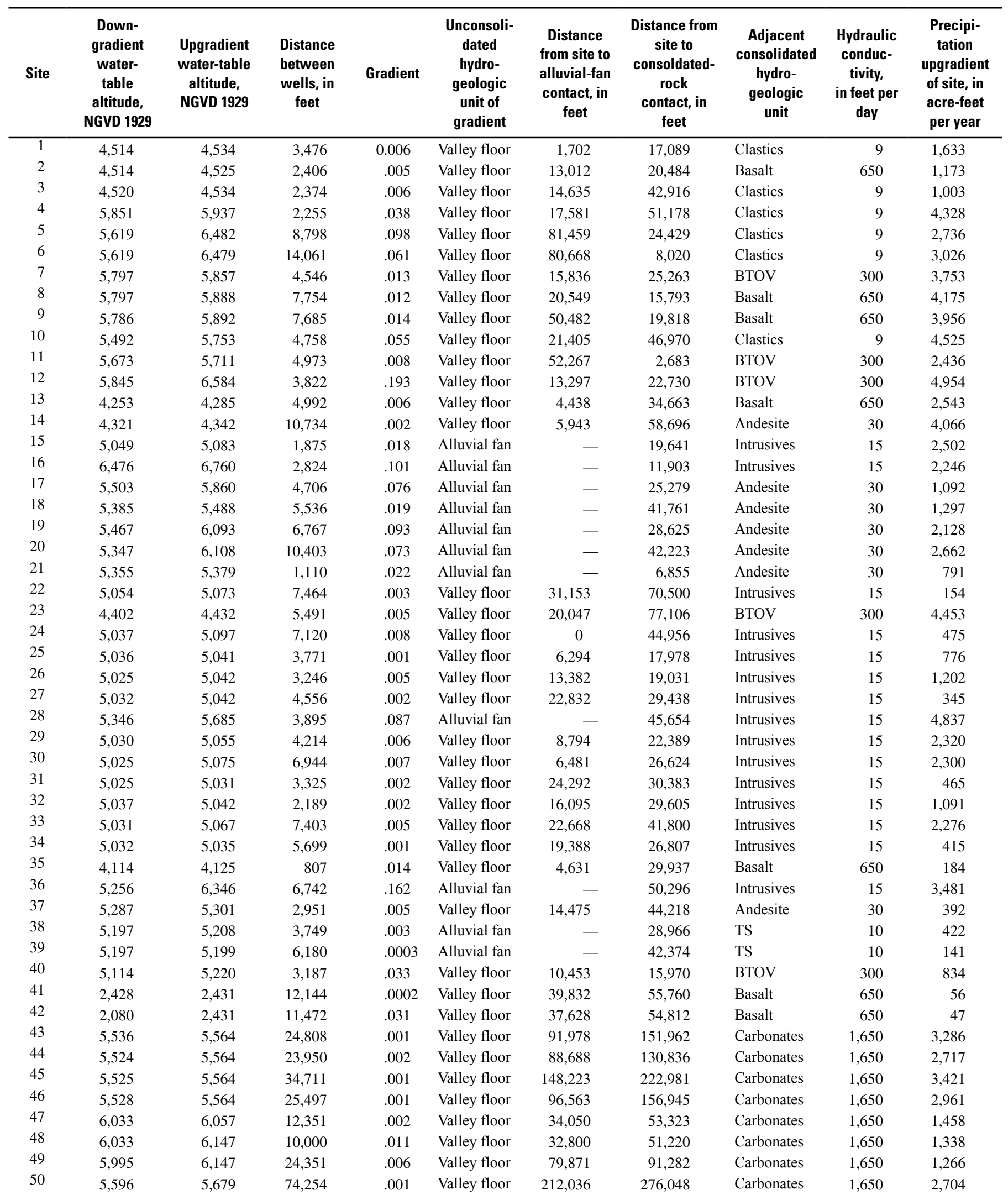


Table 2. Information used to characterize water-table gradients in Nevada-Continued

\begin{tabular}{|c|c|c|c|c|c|c|c|c|c|c|}
\hline Site & $\begin{array}{l}\text { Down- } \\
\text { gradient } \\
\text { water- } \\
\text { table } \\
\text { altitude, } \\
\text { NGVD 1929 }\end{array}$ & $\begin{array}{c}\text { Upgradient } \\
\text { water-table } \\
\text { altitude, } \\
\text { NGVD } 1929\end{array}$ & $\begin{array}{c}\text { Distance } \\
\text { between } \\
\text { wells, in } \\
\text { feet }\end{array}$ & Gradient & $\begin{array}{c}\text { Unconsoli- } \\
\text { dated } \\
\text { hydro- } \\
\text { geologic } \\
\text { unit of } \\
\text { gradient }\end{array}$ & $\begin{array}{c}\text { Distance } \\
\text { from site to } \\
\text { alluvial-fan } \\
\text { contact, in } \\
\text { feet }\end{array}$ & $\begin{array}{l}\text { Distance from } \\
\text { site to } \\
\text { consoldated- } \\
\text { rock } \\
\text { contact, in } \\
\text { feet }\end{array}$ & $\begin{array}{c}\text { Adjacent } \\
\text { consolidated } \\
\text { hydro- } \\
\text { geologic } \\
\text { unit }\end{array}$ & $\begin{array}{l}\text { Hydraulic } \\
\text { conduc- } \\
\text { tivity, } \\
\text { in feet per } \\
\text { day }\end{array}$ & $\begin{array}{l}\text { Precipi- } \\
\text { tation } \\
\text { upgradient } \\
\text { of site, in } \\
\text { acre-feet } \\
\text { per year }\end{array}$ \\
\hline 51 & 5,596 & 5,631 & 92,788 & .0004 & Valley floor & 323,152 & 382,012 & Carbonates & 1,650 & 1,813 \\
\hline 52 & 5,541 & 5,641 & 12,040 & .008 & Alluvial fan & - & 94,959 & Carbonates & 1,650 & 2,252 \\
\hline 55 & 5,109 & 5,536 & 14,831 & .029 & Alluvial fan & - & 76,860 & Clastics & 9 & 1,433 \\
\hline 56 & 5,109 & 5,617 & 16,203 & .031 & Alluvial fan & - & 112,245 & Carbonates & 1,650 & 2,398 \\
\hline 57 & 5,442 & 5,550 & 11,509 & .009 & Valley floor & 10,178 & 62,028 & Carbonates & 1,650 & 11,372 \\
\hline 58 & 6,402 & 6,411 & 5,949 & .002 & Valley floor & 29,382 & 43,837 & BTOV & 300 & 4,378 \\
\hline
\end{tabular}

Table 3. Water-table measurements for Vicee Canyon, Pine Nut Creek, and Kyle Canyon, Nevada.

[Abbreviations: USGS, U.S. Geological Survey; NGVD, National Geodetic Vertical Datum; —, no data; NA, not applicable]

\begin{tabular}{|c|c|c|c|c|c|c|c|c|}
\hline \multirow[b]{2}{*}{$\begin{array}{c}\text { USGS } \\
\text { well } \\
\text { number }\end{array}$} & \multirow[b]{2}{*}{$\begin{array}{l}\text { Land- } \\
\text { surface } \\
\text { altitude, } \\
\text { NGVD } 1929\end{array}$} & \multirow[b]{2}{*}{$\begin{array}{c}\text { Distance } \\
\text { from well } \\
\text { at lowest } \\
\text { altitude, } \\
\text { in miles }\end{array}$} & \multicolumn{3}{|c|}{ Initial measurement } & \multicolumn{3}{|c|}{ Recent measurement } \\
\hline & & & $\begin{array}{c}\text { Date of } \\
\text { water-level } \\
\text { measure- } \\
\text { ment }\end{array}$ & $\begin{array}{c}\text { Depth to } \\
\text { water, } \\
\text { in feet } \\
\text { below } \\
\text { land } \\
\text { surface }\end{array}$ & $\begin{array}{c}\text { Water- } \\
\text { table } \\
\text { altitude, } \\
\text { NGVD } \\
1929\end{array}$ & $\begin{array}{c}\text { Date of } \\
\text { water-level } \\
\text { measurement }\end{array}$ & $\begin{array}{l}\text { Depth to } \\
\text { water, in } \\
\text { feet below } \\
\text { land sur- } \\
\text { face }\end{array}$ & $\begin{array}{c}\text { Water- } \\
\text { table } \\
\text { altitude, } \\
\text { NGVD 1929 }\end{array}$ \\
\hline \multicolumn{9}{|c|}{ Vicee Canyon } \\
\hline 391100119465101 & 4,785 & .59 & Sep 9, 1997 & 40.00 & $4,745.00$ & Jan 20, 2004 & 85.10 & $4,699.90$ \\
\hline 391110119470501 & 4,800 & .88 & Jul 17, 1975 & 45.16 & $4,754.84$ & Oct 15,2003 & 100.48 & $4,699.52$ \\
\hline 391057119471901 & 4,860 & 1.10 & Jul 8, 1972 & 94.00 & $4,766.00$ & Jan 20, 2004 & 162.96 & $4,697.04$ \\
\hline 391055119473301 & 4,927 & 1.27 & - & - & - & Jan 20, 2004 & 232.84 & $4,694.16$ \\
\hline 391105119481101 & $5,181.5$ & 1.86 & Aug 4, 1994 & 139.00 & $5,042.50$ & Jan 20, 2004 & 140.80 & $5,040.70$ \\
\hline \multicolumn{9}{|c|}{ Pine Nut Creek } \\
\hline 385604119415001 & $4,897.90$ & .56 & Jan 18, 2000 & 69.90 & $4,828.00$ & Oct 19,2001 & 74.90 & $4,823.00$ \\
\hline 385554119414701 & $4,920.60$ & .65 & Jan 28, 2000 & 96.30 & $4,824.30$ & - & - & - \\
\hline 385606119411501 & $4,949.00$ & 1.00 & Jan 18, 2000 & 110.20 & $4,838.80$ & Oct 19,2001 & 124.36 & $4,824.64$ \\
\hline 385559119411801 & $4,932.60$ & 1.04 & Jan 18, 2000 & 83.40 & $4,849.20$ & Oct 19,2001 & 96.70 & $4,835.90$ \\
\hline 385559119411301 & $4,938.70$ & 1.12 & Jan 24, 2000 & 91.00 & $4,847.70$ & Oct 19,2001 & 102.86 & $4,835.84$ \\
\hline 385541119410601 & $4,957.40$ & 1.30 & Jan 6, 2000 & 110.70 & $4,846.70$ & Oct 19,2001 & 119.79 & $4,837.61$ \\
\hline 385602119401301 & $5,005.00$ & 1.92 & NA & NA & NA & Oct 19,2001 & 17.30 & $4,987.70$ \\
\hline \multicolumn{9}{|c|}{ Kyle Canyon } \\
\hline 361939115154801 & 2,454 & 0.00 & Feb 9, 1980 & 68.95 & $2,385.05$ & - & - & - \\
\hline 361924115200301 & 3,040 & 3.95 & Dec 1, 1969 & 510.00 & $2,530.00$ & - & - & - \\
\hline 361544115365101 & 7,040 & 20.10 & Feb 28, 1980 & 220.80 & $6,819.20$ & - & - & - \\
\hline
\end{tabular}


table contours are perpendicular to the consolidated-rock contact, which would indicate no inflow from the mountain front. Most water-table contours are based on measurements on the valley floor and may have been incorrectly extrapolated to the consolidated-rock contact. Few measurements were made on alluvial fans and near the consolidated-rock contact, presumably because there are few wells to measure in these areas.

Depth to water is commonly less than $50 \mathrm{ft}$ beneath valley floors, 50 to $500 \mathrm{ft}$ beneath alluvial fans, and greater than 500 $\mathrm{ft}$ in a few areas, such as north-central and southern Nevada (plate 3). Depth to water in unconsolidated sediments could be related to recharge, the proximity to and horizontal hydraulic conductivity of nearby consolidated rock, the amount and proximity of pumping, and whether the basin is hydraulically open or closed (Maurer and others, 2004, fig. 1).

Greasewood is a phreatophyte and a good indicator of a shallow water table. Greasewood, mapped by the Gap Analysis Program (GAP; Edwards and others, 1996), is the predominant species over $3,700 \mathrm{mi}^{2}$ of Nevada (fig. 7). However, greasewood also occurs in areas where it is not the predominant species. About 80 percent of the greasewood grows in areas where depth-to-water surfaces were made. In these areas, 81 percent of the greasewood is where depth to water is less than $50 \mathrm{ft}, 10$ percent is where depth to water is 50 to $100 \mathrm{ft}$, and 9 percent is where depth to water is greater than $100 \mathrm{ft}$ it is unlikely that greasewood could grow where depth to water is greater than $50 \mathrm{ft}$, unless the roots are tapping into perched aquifers, which do not represent the regional water table. Greasewood growing where depth to water is greater than $50 \mathrm{ft}$ also could reflect differences in resolution between GAP and the depth-to-water surfaces. In general, the presence of greasewood in figure 7 in areas for which no surface has been made indicates areas where the water table has not been mapped and where depth to water likely is less than $50 \mathrm{ft}$.

Ground-water discharge areas are areas where shallow ground water evaporates from the soil and is transpired by vegetation (Harrill and others, 1988). Ground-water discharge areas cover about $11,000 \mathrm{mi}^{2}$, about 10 percent of Nevada (fig. 8). However, only about 50 percent of the greasewood is within ground-water discharge areas, indicating that some ground-water discharge areas have not been mapped (fig. 8; Edwards and others, 1996). The largest areas of greasewood outside ground-water discharge areas are in the Black Rock Desert (HA 28) and Desert Valley (HA 31). Where water-table surfaces overlap ground-water discharge areas, depth to water is generally less than $100 \mathrm{ft}$. Discharge areas that do not overlap a surface indicate areas where the water table has not been mapped and where depth to water is less than $100 \mathrm{ft}$.

Temporal changes in water-table levels were evaluated for 1,981 wells with 10 years or more between the first and last depth-to-water measurements made since 1990. Temporal changes were calculated by subtracting the last depth-to-water measurement from the first measurement. Positive values of temporal change indicate the water table has dropped and negative values indicate the water table has risen. Temporal changes were related to well depth, number of years between measurements, and the first depth-to-water measurement (fig. 9). The time between measurements ranged from 10 to 102 years, with a mean of 27 years. Four wells in southern Nevada had depth to water that changed by more than $\pm 400 \mathrm{ft}$. These four wells, not plotted in figure 9, are in Kawich Valley (HA 157; $738 \mathrm{ft}$ ), Yucca Flat (HA 159; $836 \mathrm{ft}$ ), Gold Flat (HA 147; $-863 \mathrm{ft}$ ), and Hot Creek (HA 156; -1,592 ft).

A paired t-test between first and last depth-to-water measurements indicated that the measurements are significantly different (p-value $<0.01$ ). Depth to water has increased by an average of $5 \mathrm{ft}$. The greatest increases in depth to water occurred where the first measurement was less than $200 \mathrm{ft}$, where the time between first and last measurements was 40 years or less, and for wells $100 \mathrm{ft}$ to $600 \mathrm{ft}$ deep (fig. 9). These characteristics describe production wells where the water table is fairly shallow in recently developing areas such as the Las Vegas and Reno metropolitan areas. The water table has changed little in wells that are less than $100 \mathrm{ft}$ or greater than $1,000 \mathrm{ft}$ deep or with more than 60 years between the first and last measurements. Many of these wells are in basins with little development.

The largest increases in depth to water occurred in the Middle Reese River Valley (HA 58), Eagle Valley (HA 104), Smith Valley (HA 107), Mason Valley (HA 108), Yucca Flat (HA 159), and Las Vegas Valley (HA 212; fig. 10). Except for Yucca Flat, these HAs are areas where large amounts of ground water have been pumped for agricultural irrigation and municipal supply (Lopes and Evetts, 2004). Natural variations in water-table levels due to climate and recharge were determined using 444 measurements in HAs where pumpage during 2000 was 10 percent or less of the average annual natural recharge (Lopes and Evetts, 2004). These HAs include 2-8, 10-21, 23, 25-28, 34-44, 46, 47, 50, 53, 55, 62, 63, 68, 79-82, 94, 95, 96, 98, 99, 106, 109, 111-116, 118-121, 124, $125,127,130,131,132,134-136,138-141,144,145,147$, $148,150,151,152,155,157,158,161,168,169,171-176$, 178-182, 184, 185, 186, 188, 189, 190, 192-197, 200, 201, 204-208, 210, 211, 217, 221, 227, 231, and 232. The change in depth to water in these HAs is normally distributed, with a mean of $-1 \mathrm{ft}$ and a standard deviation of $30 \mathrm{ft}$. A two-sided t-test indicated that the mean is not significantly different than zero (p-value $=0.6$ ). Ninety percent of the changes are within $\pm 20 \mathrm{ft}$, which is about the natural fluctuation in the water table.

\section{Water-Table Gradients}

Water-table gradients were characterized between pairs of wells at 58 sites in Nevada. The 16 gradients measured beneath alluvial fans ranged from 0.0003 to 0.2 and had a median of 0.02 , a mean of 0.04 , and a standard deviation of 0.05 . The 42 gradients measured beneath valley floors ranged from 0.0002 to 0.3 and had a median of 0.005 , a mean of 0.03 , and a standard deviation of 0.07 . In comparison, previ- 


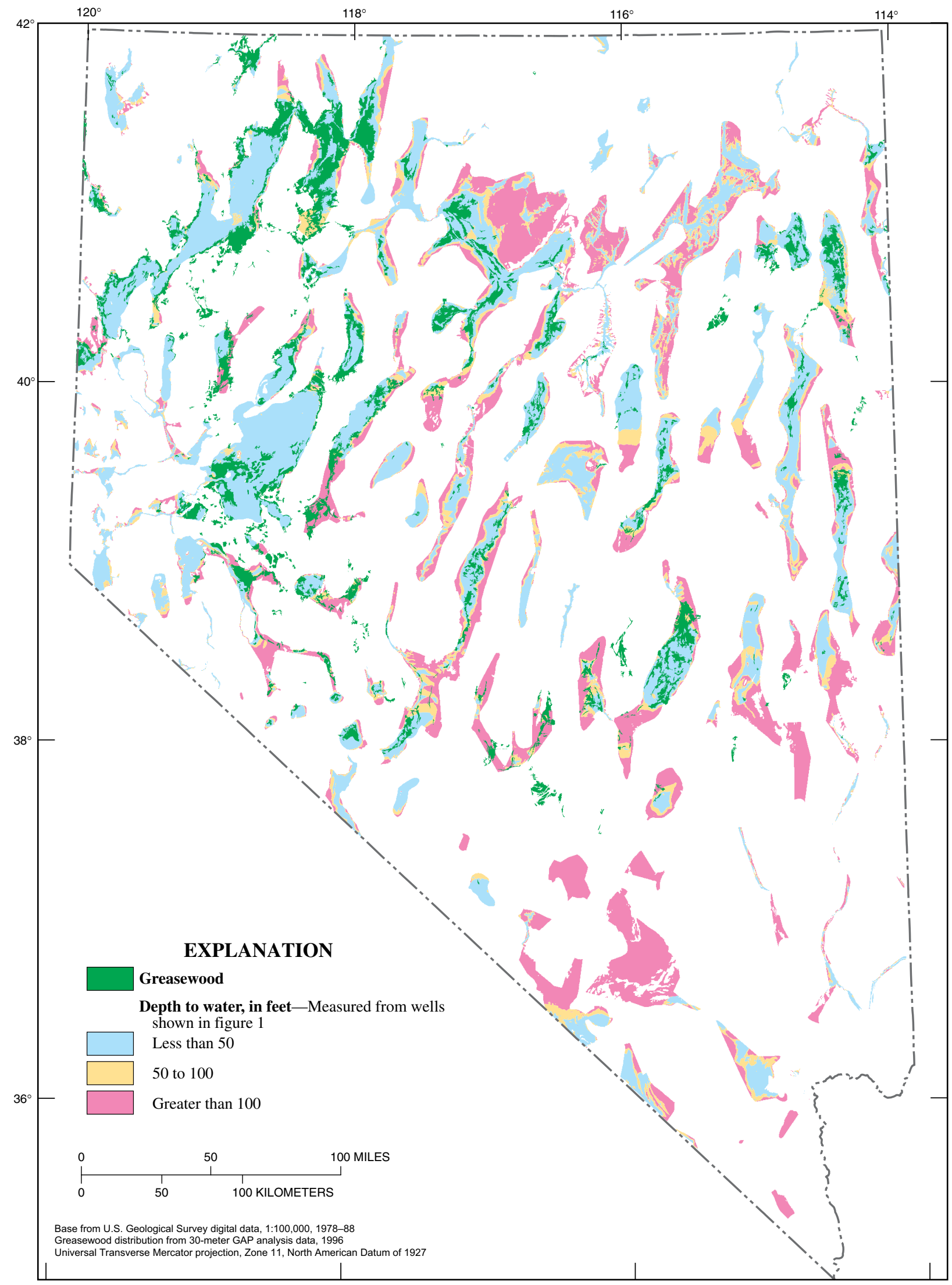

Figure 7. Depth-to-water surfaces and areas of predominantly greasewood. 


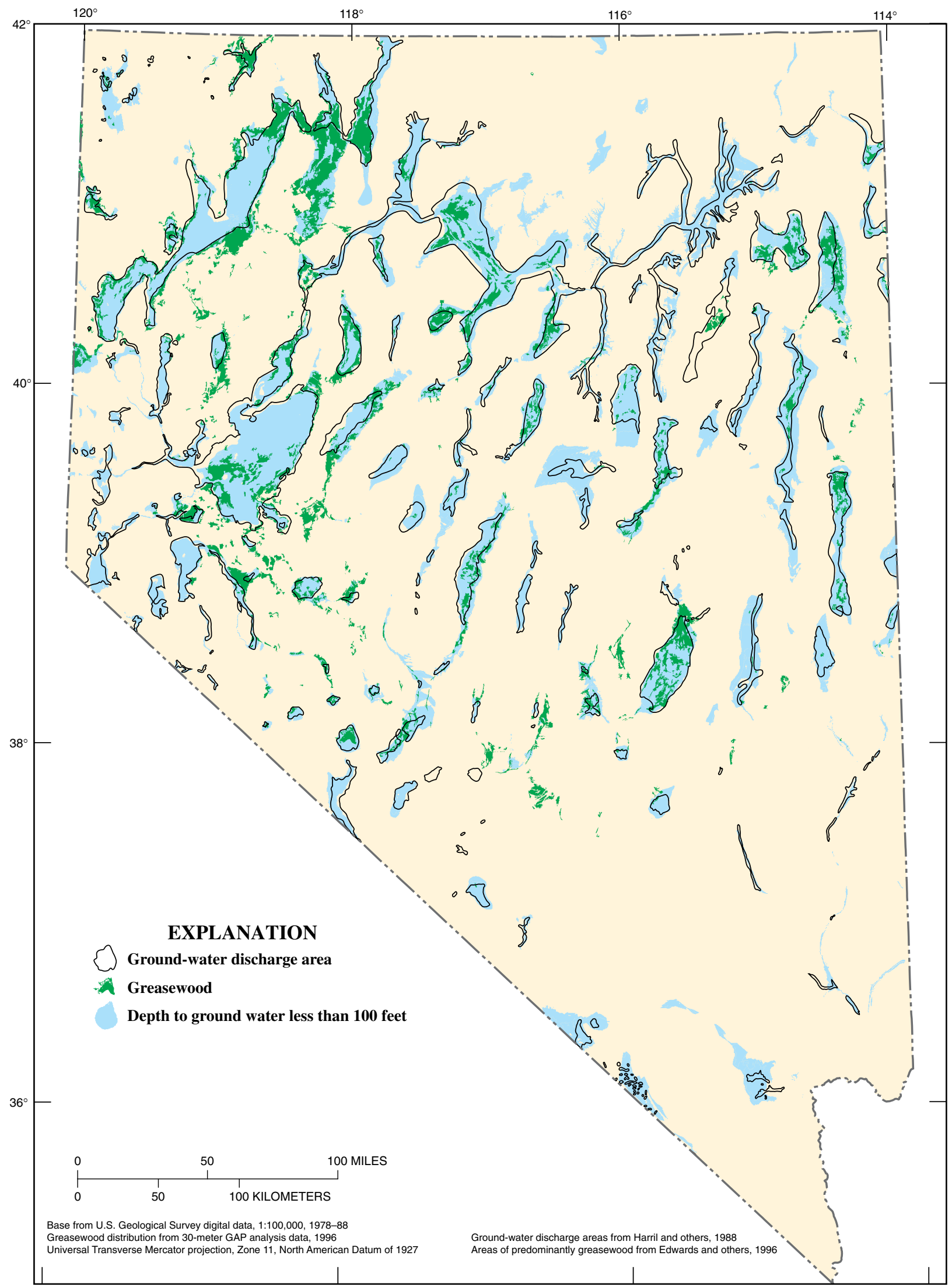

Figure 8. Ground-water discharge areas, areas of predominantly greasewood, and depth-to-water less than 100 feet. 


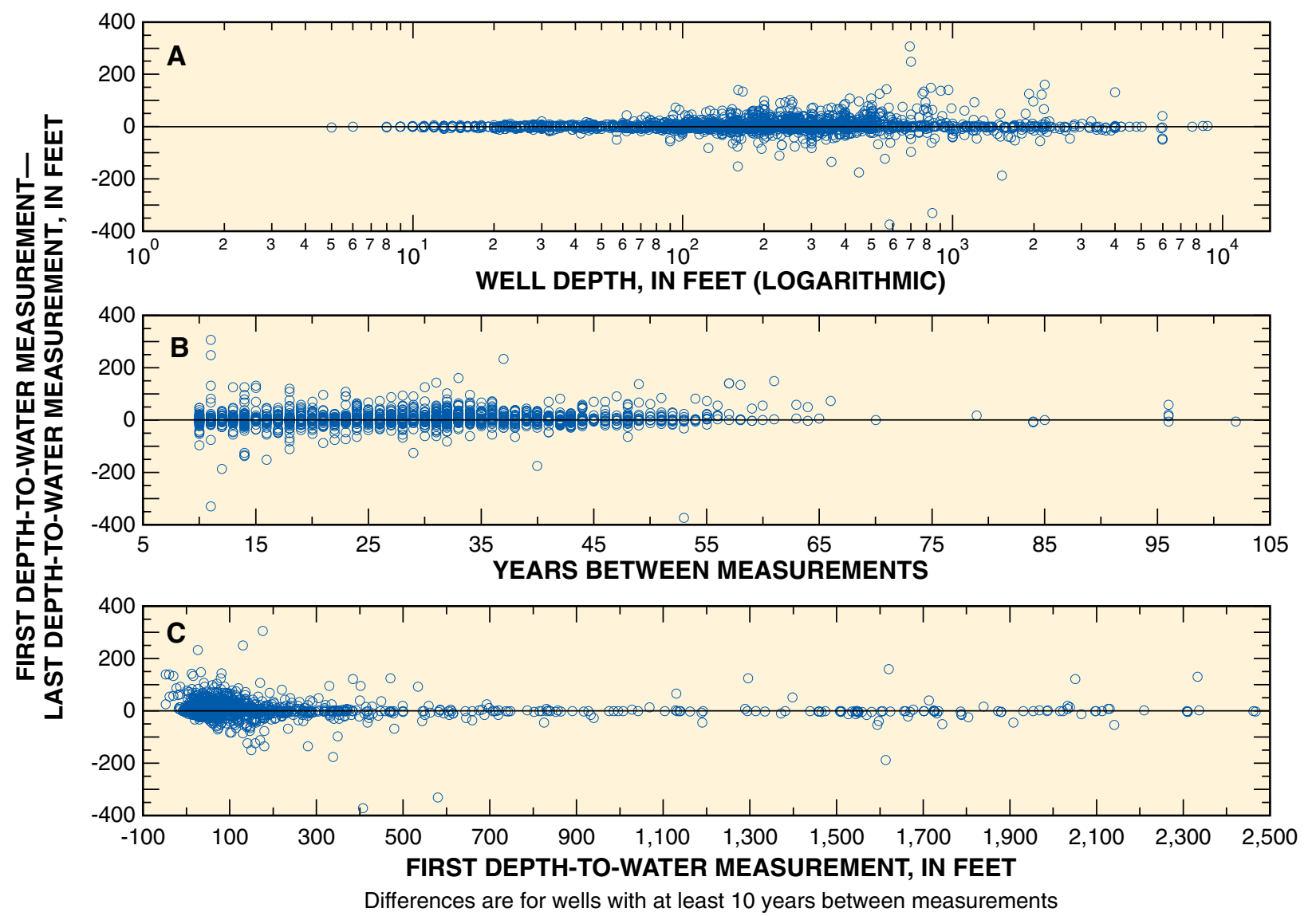

Figure 9. Differences between last and first depth-to-water measurements versus $\mathbf{A}$, well depth, B, years between measurements, and $\mathbf{C}$, first depth-to-water measurement.

ous studies in Nevada measured gradients beneath alluvial fans that range from 0.005 to 0.02 and beneath valley floors from 6 x $10-7$ to 0.002 (Handman and Kilroy, 1997, p. 61; Harrill and Preissler, 1994, p. 10; Maurer, 1986, p. 17; Prudic and Herman, 1996, p. 16; Thomas and others, 1989, pl. 2). Gradients between 26 wells in basin fill and consolidated rock and the lake-surface altitude of Lake Tahoe ranged from 0.001 to 0.120 and had a median of 0.02 , a mean of 0.02 , and a standard deviation of 0.03 (Thodal, 1997, p. 24).

Gradients from this study, horizontal hydraulic conductivity from Maurer and others (2004), effective porosity, and equation 1 can be used to estimate ground-water velocities in Nevada. Effective porosity is closely approximated by specific yield, which is a more commonly measured variable. Specific yield is the fraction of the saturated aquifer that drains by gravity when the water table drops. Effective porosity and specific yield exclude isolated pores and water that is too strongly adsorbed to clay and other particles to drain. Porosity and specific yield depend on variables such as particle size, degree of sorting, and depth (Cohen, 1963; Johnson, 1967). Basins that have large, flow-through rivers tend to have well-sorted sediments and higher specific yields than other basins. For example, the median specific yield of Carson Valley is 21 per- cent, compared to 10 to 14 percent for Paradise Valley, Smith Creek Valley, and Stagecoach Valley (Harrill and Prudic, 1998, table 7).

Alluvial fans have a median gradient of 0.02 and a mean horizontal hydraulic conductivity of about $70 \mathrm{ft} / \mathrm{d}$ and valley floors have a median gradient of 0.005 and a mean horizontal hydraulic conductivity of about $45 \mathrm{ft} / \mathrm{d}$ (Maurer and others, 2004 , table 2). An effective porosity of 0.12 was used for alluvial fans and 0.2 for well-sorted sand and gravel in valley floors. Using these values in equation 1, the average linear velocity of ground water beneath alluvial fans is about $14 \mathrm{ft} / \mathrm{d}$, compared to about $1 \mathrm{ft} / \mathrm{d}$ beneath valley floors. This indicates that contaminants travel roughly 10 times faster beneath alluvial fans than beneath valley floors, depending on the physical and chemical properties of the aquifer material and the contaminant.

Like the t-test, the two-sided Wilcoxon rank-sum test compares differences between two populations, but the Wilcoxon rank-sum test is more appropriate for small sample sizes. The Wilcoxon rank-sum test indicated that gradients beneath alluvial fans are significantly larger ( $p$-value $=0.01$ ) than gradients beneath valley floors, even though the largest gradients were measured beneath valley floors (fig. 11A). This 


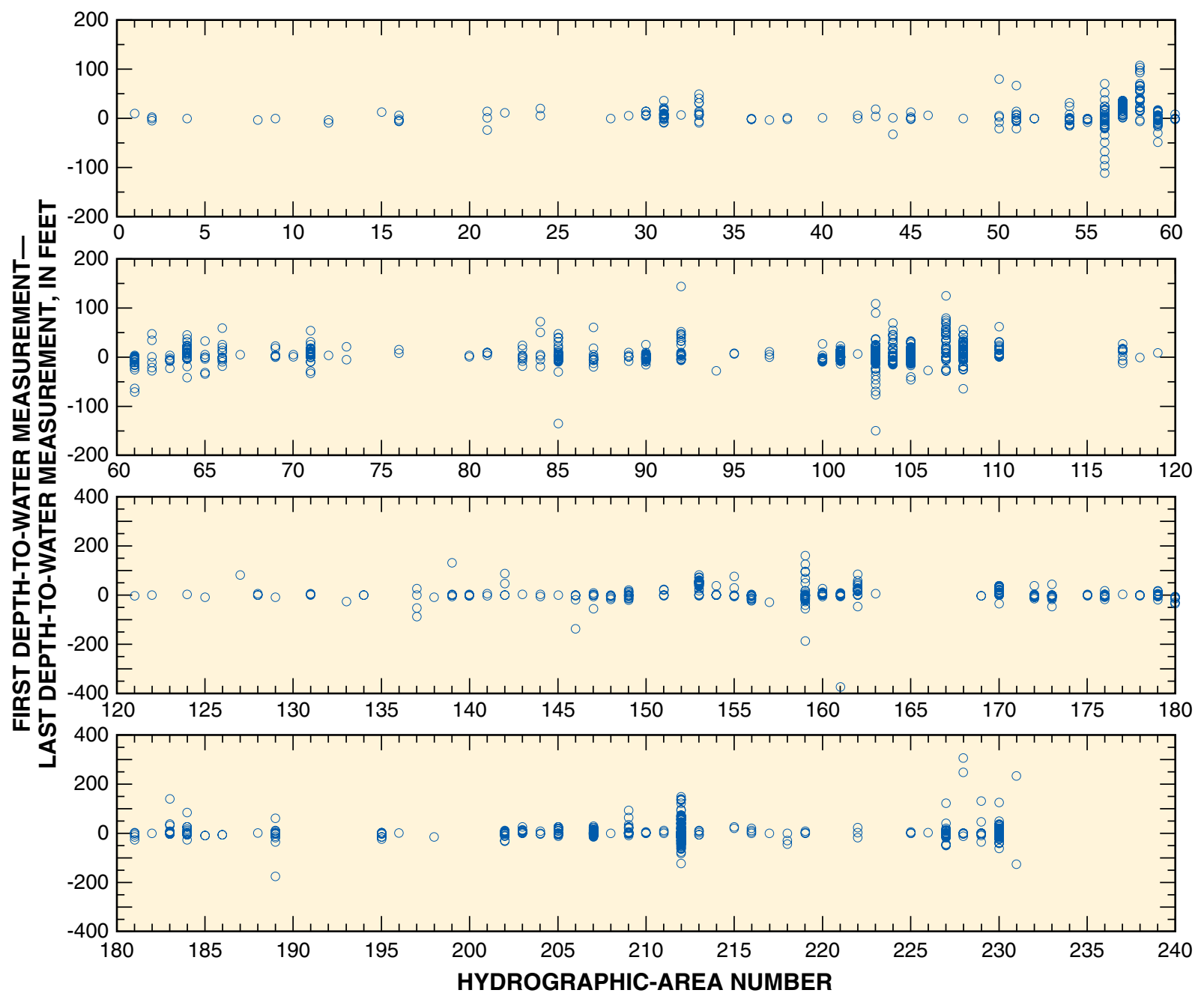

Differences are for wells with 10 or more years between measurements. See figure 1 for hydrographic-area names and locations

Figure 10. Differences between last and first depth-to-water measurements grouped by hydrographic-area number.

finding is consistent with the general description of the water table in Nevada. The large gradients measured in the valley floor could be due to error in location of the wells, the alluvial fan-valley floor contact, well altitude, or other reasons.

The Kruskal-Wallis rank test compares differences among more than two populations. This test indicated significant differences $(p$-value $=0.01)$ among gradients adjacent to different consolidated rocks (fig. 11B). These differences could be related to the horizontal hydraulic conductivity of the consolidated rocks and the sediments derived from them. The Spearman rank correlation is used to determine if a general but not necessarily linear relation exists between correlated variables. The Spearman rank correlation between the gradient and horizontal hydraulic conductivity of the consolidated rock was -0.30 ( $\mathrm{p}$-value $=0.02$; fig. $12 \mathrm{~A})$. The inverse correlation makes hydrologic sense if gradients in unconsolidated sediments are related to the horizontal hydraulic conductivity of adjacent consolidated rocks.
Spearman rank correlations were statistically significant between gradients and precipitation upgradient of the site (0.32; fig. 12B), distance to the alluvial-fan contact (-0.31), and distance to the consolidated-rock contact ( -0.41 ; fig. 12C). Although weak, these correlations also make physical sense. Decreasing gradients with increasing distance from the mountain front is consistent with the general description of the water table along mountain fronts (Eakin and others, 1976; Maurer and others, 2004) and with precipitation upgradient of a site being the driving force for gradients.

Prior to pumping, the water tables in Vicee and Kyle Canyons had similar shapes and were nearly parallel to land-surface altitudes (fig. 13). Linear regression of watertable altitude with land-surface altitude from both sites had a significant (p-value $<0.01$ ) slope of 0.89 and an r-squared of 0.97 . This relation supports using linear interpolation of watertable contours. If this relation is valid for other hydrogeologic settings, then the water table could be estimated from a few measurements in a basin. 

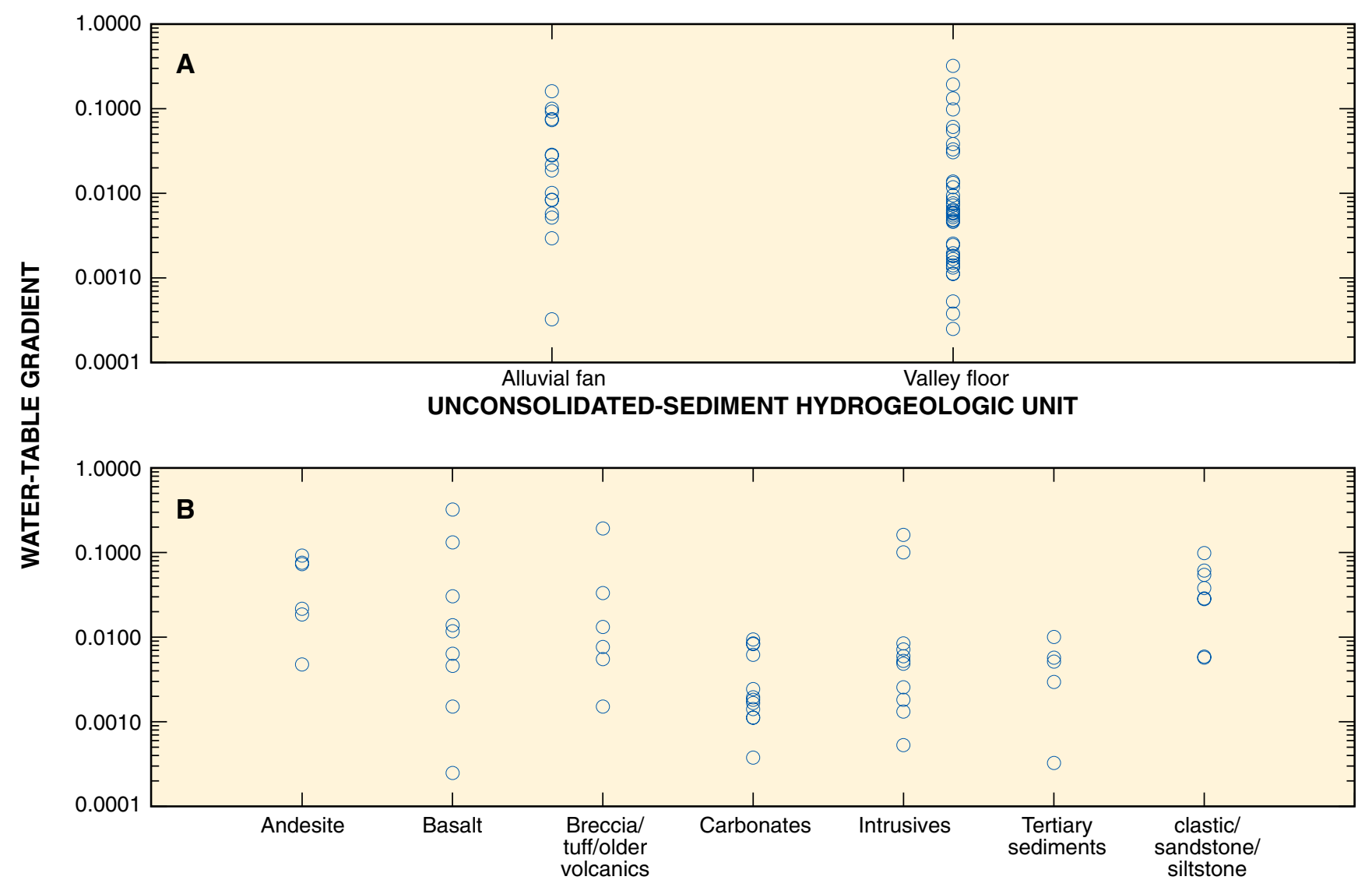

ADJACENT CONSOLIDATED-ROCK HYDROGEOLOGIC UNIT

Figure 11. Ranges in water-table gradients $\mathbf{A}$, beneath alluvial fans and valley floors and $\mathbf{B}$, grouped by adjacent consolidatedrock hydrogeologic unit.

The recent (2000-2004) water tables at Pine Nut Creek and Vicee Canyon are similar and are not parallel to landsurface altitudes. At Pine Nut Creek, the water table is fairly flat to about one mile into the alluvial fan and then changes abruptly near the consolidated-rock contact, which is similar to the recent water table at Vicee Canyon. This similarity could be due to pumping in the alluvial fan that has lowered the water table or Pine Nut Creek has unique hydrogeologic characteristics. Production wells at Vicee Canyon have had a large effect on the water table. Recent measurements indicate that the gradient has reversed, with flow from the valley floor toward the consolidated rock. The lowest water-table altitude is at mile 1.27, between the production well drilled in 1972 and the consolidated-rock contact (fig. 13), which is consistent with pumpage near a low-flow boundary. The non-linear relation at Vicee Canyon likely depends on the amount of pumpage, which would make it difficult to estimate the water table at developed sites. This study used existing data to characterize gradients. A study specifically designed to characterize gradients may result in stronger correlations that could be used to estimate gradients and the water table where few data exist.

\section{Summary}

In 1999, the U.S. Environmental Protection Agency started a program to protect the quality of ground water in areas other than ground-water protection areas. OSGWAs are areas that are not currently, but could eventually be, used as a source of drinking water. The OSGWA program specifically addresses existing wells that are used for underground injection of motor vehicle waste. If an injection well is in a ground-water protection area or an OSGWA, well owners must either close the well or apply for a permit. NDEP will evaluate site-specific information associated with the permit application and determine if the aquifer at the site is sensitive, rather than designate specific areas as OSGWAs. To evaluate permit applications, NDEP needs statewide information on depth to water and the water table, which partly control the susceptibility of ground water to contamination and contaminant transport. In a cooperative study with NDEP, the USGS used published maps and data to make statewide maps of water-table levels and characterize water-table gradients. 

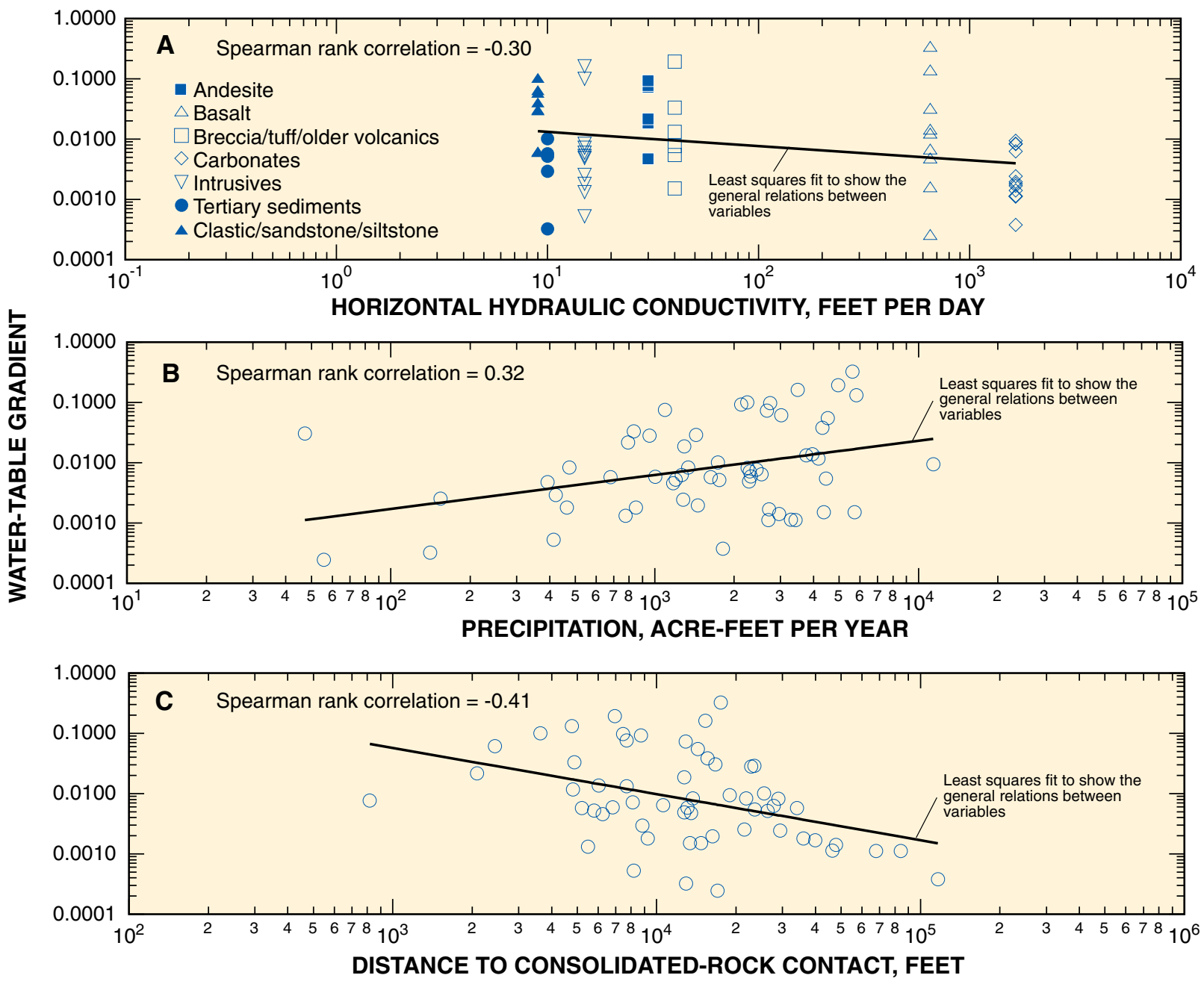

Figure 12. Water-table gradients in unconsolidated sediments versus $\boldsymbol{A}$, horizontal hydraulic conductivity of adjacent consolidated hydrogeologic unit, $\boldsymbol{B}$, upgradient precipitation, and $\boldsymbol{C}$, distance to consolidated-rock contact.

A literature search of published water-table and depthto-water contours produced maps of varying detail and scope in 104 reports published from 1948 to 2004. Twenty-eight maps had depth-to-water contours and 90 maps had watertable contours. The most recent, detailed maps that covered the largest area and had plotted control points were chosen for this study. Where multiple maps covered the same HA, the map that covered multiple HAs was chosen. These selection criteria resulted in water-table and depth-to-water contours that are based on data collected from 1947 to 2004 being selected from 39 reports. If not already available digitally, contours and control points were digitized from selected maps, entered into a GIS, and combined to make a statewide map of water-table contours. Water-table surfaces were made by using inverse-distance weighting to estimate the water table between contours and gridding the estimates. Depth-to-water surfaces were made by subtracting water-table altitude from land-surface altitude.
Water-table and depth-to-water surfaces were made for only 21 percent of Nevada due to a lack of information for 49 of 232 HAs and in most consolidated-rock hydrogeologic units. Depth to water is commonly less than 50 feet beneath valley floors, 50 to 500 feet beneath alluvial fans, and greater than 500 feet in some areas such as north-central and southern Nevada. In areas without water-table information, greasewood and mapped ground-water discharge areas are good indicators of depth to water that is less than 100 feet. The accuracy of the surfaces was evaluated by comparing depth to water measured at 682 wells with depth to water estimated from depth-towater surfaces. The average difference between measured and estimated depth to water was 90 feet. To evaluate a specific site, more recent and detailed data may be needed.

The greatest increases in depth to water occurred where the first measurement was less than 200 feet, where the time between first and last measurements was 40 years or less, and for wells 100 feet to 600 feet deep. These characteristics describe production wells where ground water is fairly shallow 

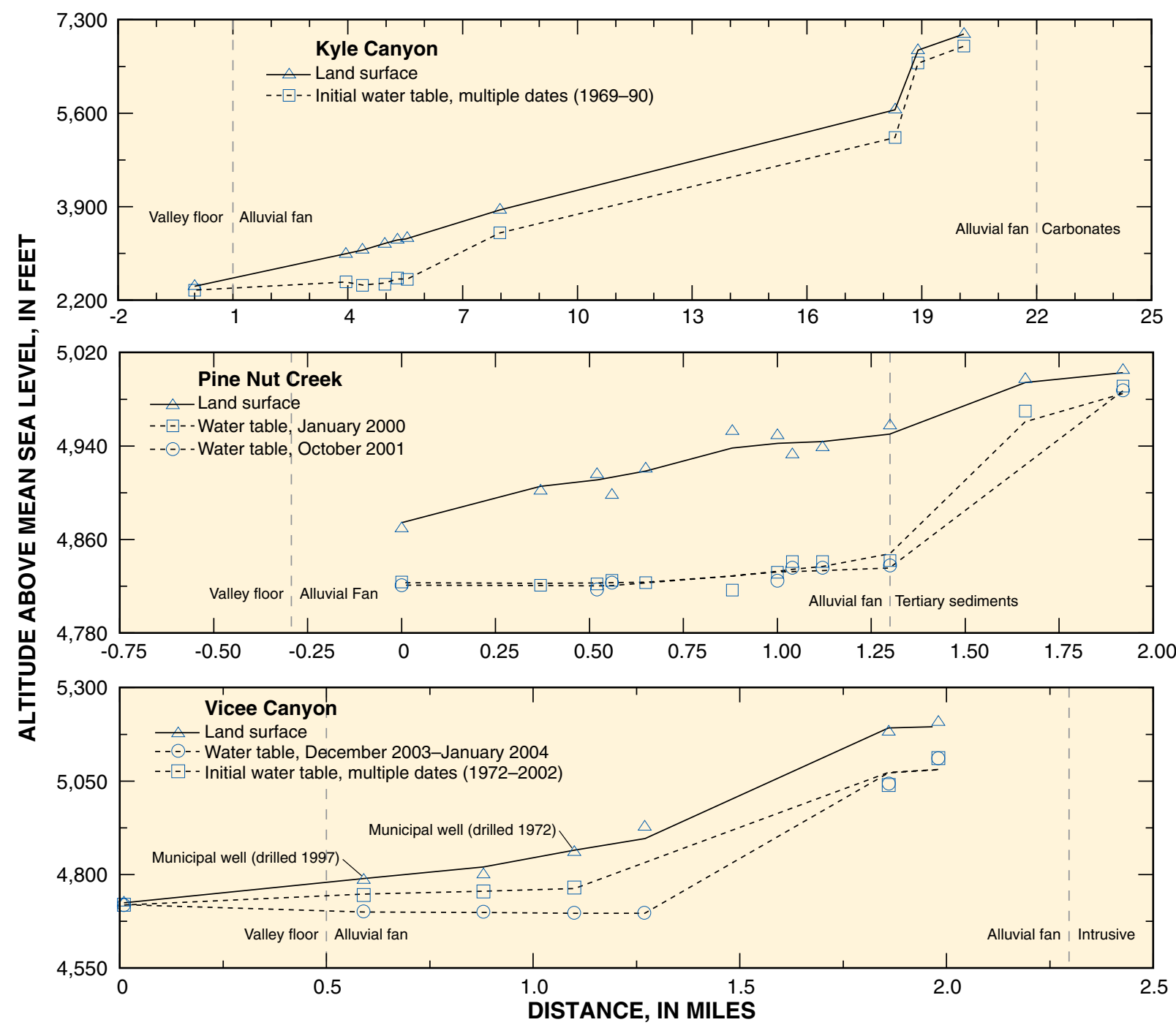

Ground-water levels measured on multiple dates were used to approximate the initial ground-water altitude surface. Lines were fit using kernel smoothing

Figure 13. Water-table and land-surface altitude versus distance from the well at the lowest land-surface altitude in Kyle Canyon, Pine Nut Creek, and Vicee Canyon.

in recently developing areas such as the Las Vegas and Reno metropolitan areas. In basins with little pumping, 90 percent of the changes during the past 100 years are within \pm 20 feet, which is about the natural variation to expect in the water table due to changes in the climate and recharge.

Gradients in unconsolidated sediments of the Great Basin are generally steep near mountain fronts and shallow beneath valley floors. Variables that could affect gradients in unconsolidated sediments include the source rock and texture of unconsolidated sediments, amount of recharge and distance from recharge areas, and other variables such as the horizontal hydraulic conductivity of adjacent consolidated rocks. To identify important variables, gradients beneath alluvial fans and valley floors at 58 sites were correlated with the distance to the alluvial-fan contact, distance to and horizontal hydraulic conductivity of the adjacent consolidated hydrogeologic unit, and precipitation upgradient of the sites. In addition, water-level measurements were used to characterize the water table between the valley floor and consolidated rock at Vicee Canyon in Eagle Valley, Pine Nut Creek in Carson Valley, and Kyle Canyon in Las Vegas Valley.

Water-table gradients beneath alluvial fans ranged from 0.0003 to 0.2 and had a median of 0.02 , a mean of 0.04 , and a standard deviation of 0.05 . Gradients beneath valley floors ranged from 0.0002 to 0.3 and had a median of 0.005 , a mean of 0.03 , and a standard deviation of 0.07. Information from this and other reports suggest that the average linear velocity of ground water is roughly 10 times faster beneath alluvial fans than beneath valley floors. Contaminants may travel about 10 times faster beneath alluvial fans than beneath valley floors, depending on the physical and chemical properties of the aquifer material and contaminant.

Gradients associated with different types of consolidated rocks are significantly different, which could be related to the 
horizontal hydraulic conductivity of the consolidated rocks and the sediments derived from them. Spearman rank correlations were statistically significant between gradients and the horizontal hydraulic conductivity of adjacent consolidatedrock hydrogeologic units $(-0.30)$, precipitation upgradient of the site (0.32), distance to the alluvial-fan contact (-0.31), and distance to the consolidated-rock contact (-0.41). These relations are consistent with the general description of the water table along mountain fronts and with precipitation being the driving force for gradients.

Before large pumping in Vicee and Kyle Canyons, the water tables in both areas were similar and were nearly parallel to land-surface altitude. Linear regression of water-table altitude with land-surface altitude from both sites had a slope of 0.89 and an r-squared of 0.97 . If this relation is valid for other hydrogeologic settings, then the water table could be estimated from a few measurements in a basin. The recent water tables at both Pine Nut Creek and Vicee Canyon were not parallel with land-surface altitude. This similarity could be due to pumpage in the alluvial fan that has lowered the water table or Pine Nut Creek has unique hydrogeologic characteristics. Production wells in Vicee Canyon have reversed the gradient and caused ground water to flow from the valley floor toward the consolidated rock. The non-linear relation at Vicee Canyon likely depends on the amount of pumpage, which would make it difficult to estimate water-table levels at developed sites. This study used existing data to characterize gradients. A study specifically designed to characterize gradients may result in stronger correlations that could be used to estimate gradients and the water table where few data exist.

\section{References Cited}

Bedinger, M.S., Harrill, J.R., Langer, W.H., Thomas, J.M., and Mulvihill, D.A., 1984, Maps showing ground-water levels, springs, and depth to water, Basin and Range Province, Nevada: U.S. Geological Survey Water-Resources Investigations Report 83-4119-B, 2 sheets, scale 1:500,000.

Berger, D.L., and Medina, R.L., 1999, Spatial ground-water data base in Carson Valley, Douglas County, Nevada, and Alpine County, California-Development and documentation: U.S. Geological Survey Water-Resources Investigations Report 99-4188, 1 CD-ROM.

Cardinalli, J.L., Roach, L.M., Rush, F.E., and Vasey, B.J., 1968, State of Nevada hydrographic areas: Nevada Division of Water Resources map, scale 1:500,000.

Cohen, Philip, 1963, Specific yield and particle-size relations of Quaternary alluvium, Humboldt River Valley, Nevada: U.S. Geological Survey Water-Supply Paper 1669-M, 24 p.
Eakin, T.E., 1962, Ground-water appraisal of Diamond Valley, Eureka and Elko Counties, Nevada: Nevada Department of Conservation and Natural Resources, Ground-Water Resources - Reconnaissance Report 6, 60 p.

Eakin, T.E., Price, Don, and Harrill, J.R., 1976, Summary appraisals of the Nation's ground-water resources-Great Basin Region: U.S. Geological Survey Professional Paper 813-G, 37 p.

Edwards, T.C., Jr., Homer, C.G., and Bassett, S.D., 1996, Nevada GAP Analysis-An environmental information system: Unpublished technical report 96-5, Logan, Utah, Utah Cooperative Fish and Wildlife Research Unit, Utah State University, 435 p., plus 2 CD-ROMs.

Freeze, R.A., and Cherry, J.A., 1979, Groundwater: New Jersey, Prentice-Hall, Inc., 604 p.

Handman, E.H., and Kilroy, K.C., 1997, Ground-water resources of northern Big Smoky Valley, Lander and Nye Counties, central Nevada: U.S. Geological Survey WaterResources Investigations Report 96-4311, 97 p.

Handman, E.H., Londquist, C.J., and Maurer, D.K., 1990, Ground-water resources of Honey Lake Valley, Lassen County, California, and Washoe County, Nevada: U.S. Geological Survey Water-Resources Investigations Report 90-4050, 112 p.

Harrill, J.R., Gates, J.S., and Thomas, J.M., 1988, Major ground-water flow systems in the Great Basin region of Nevada, Utah, and adjacent States: U.S. Geological Survey Hydrologic Investigations Atlas HA-694-C, scale $1: 1,000,000,2$ sheets.

Harrill, J.R., and Preissler, A.M., 1994, Ground-water flow and simulated effects of development in Stagecoach Valley, a small, partly drained basin in Lyon and Storey Counties, Western Nevada: U.S. Geological Survey Professional Paper 1409-H, 74 p.

Harrill, J.R., and Prudic, D.E., 1998, Aquifer systems in the Great Basin Region of Nevada, Utah, and adjacent statesSummary report: U.S. Geological Survey Professional Paper 1409-A, 66 p.

Helsel, D.R., and Hirsch, R.M., 1992, Statistical methods in water resources: New York, Elsevier Science Publishers., 522 p.

Huxel, C.J., Jr., and Harris, E.E., 1969, Water resources and development in Mason Valley, Lyon, and Mineral Counties, Nevada, 1948-65: Nevada Division of Water Resources, Bulletin 38, 77 p.

Johnson, A.I., 1967, Specific yield-Compilation of specific yields for various materials: U.S. Geological Survey WaterSupply Paper 1662-D, 74 p 
Lopes, T.J., and Evetts, D.E., 2004, Ground-water pumpage and artificial recharge for 2000 and average annual natural recharge and interbasin flow by hydrographic area: U.S. Geological Survey Scientific Information Report 20045239, 87 p.

Lopes, T.J., 2006, Quality of Nevada's aquifers and their susceptibility to contamination, 1990-2004: U.S. Geological Survey Scientific Investigations Report 2006-5127, 52 p.

Maurer, D.K., 1986, Geohydrology and simulated response to ground-water pumpage in Carson Valley-A river-dominated basin in Douglas County, Nevada, and Alpine County, California: U.S. Geological Survey Water-Resources Investigations Report 86-4328, 109 p.

Maurer, D.K., Lopes, T.J., and Medina, R.L., 2004, Hydrogeology and hydrologic landscape regions of Nevada: U.S. Geological Survey Scientific Investigations Report 20045131, 41 p.

National Atlas of the United States, 1998, Hydrologic units: compiled by the U.S. Geological Survey, 1:3,500,000 scale map, accessed July 12, 2004, at http://nationalatlas.gov/ hucmapwhole.html

Nevada Division of Environmental Protection, 2003, Fact sheet: accessed on December 30, 2003, and July 12, 2004, at http://ndep.nv.gov/sec/uicfact.pdf

Oregon Climate Service, 1997, Nevada average monthly or annual precipitation, 1961-1990: Corvallis, Oregon, Oregon State University, accessed July 12, 2004, at http://www.ocs. orst.edu/pub/maps/Precipitation/Total/States/NV/nv_vect_ meta.html

Peltz, L.A., Medina, R.L., and Buto, S.G., 2005, 1:750,000scale hydrographic areas and basin-wide pumpage, recharge and interbasin flow estimates of Nevada: U.S. Geological Survey data available on the Web, accessed November 29, 2005, at http://water.usgs.gov/lookup/getspatial?nv_ ha750nv

Prudic, D.E., and Herman, M.E., 1996, Ground-water flow and simulated effects of development in Paradise Valley, a basin tributary to the Humboldt River in Humboldt County, Nevada: U.S. Geological Survey Professional Paper 1409-F, $92 \mathrm{p}$.

Rush, F.E., 1968, Index of hydrographic areas in Nevada: Nevada Division of Water Resources, Information Report 6, $38 \mathrm{p}$.

Rush, F.E., 1974, Static ground water levels of Nevada: Nevada Division of Water Resources map, scale 1:750,000, 1 sheet.
Thodal, C.E., 1997, Hydrogeology of Lake Tahoe Basin, California and Nevada, and results of a ground-water quality monitoring network, water years 1990-92: U.S. Geological Survey Water-Resources Investigations Report 97-4072, $53 \mathrm{p}$.

Thomas, J.M., Carlton, S.M., and Hines, L.B., 1989, Groundwater hydrology and simulated effects of development in Smith Creek Valley, a hydrologically closed basin in Lander County, Nevada: U.S. Geological Survey Professional Paper 1409-E, 57 p.

U.S. Environmental Protection Agency, 2000, Technical Assistance Document (TAD) for delineating "Other Sensitive Ground Water Areas:” Washington, U.S. Environmental Protection Agency, Office of Water, Report 816-R-00-016, 24 p., available online at http://www.epa.gov/safewater/uic/ tad_sensitive_gw.pdf

U.S. Geological Survey, 2002, The National Map-Elevation: U.S. Geological Survey Fact Sheet 106-02, 2 p., accessed July 12, 2004, at http://ned.usgs.gov//faq.asp

U.S. Geological Survey, 2004, What is the average vertical accuracy of NED?: U.S. Geological Survey data available on the Web, accessed July 12, 2004, at http://ned.usgs. gov//faq.asp\#vertical 


\section{Appendix 1. Reports with water-level contours for Nevada.}

[Asterisk indicates report selected for this study]

*Arteaga, F.E., 1982, Mathematical model analysis of the Eagle Valley ground-water basin, west-central Nevada: U.S. Geological Survey Open-File Report 80-1224, 55 p.

*Bedinger, M.S., Harrill, J.R., Langer, W.H., Thomas, J.M., and Mulvihill, D.A., 1984, Maps showing ground-water levels, springs, and depth to water, Basin and Range Province, Nevada: U.S. Geological Survey Water-Resources Investigations Report 83-4119-B, 2 sheets, scale 1:500,000.

*Berger, D.L., 1995, Ground-water conditions and effects of mine dewatering in Desert Valley, Humboldt and Pershing Counties, northwestern Nevada, 1962-91: U.S. Geological Survey Water-Resources Investigations Report 95-4119, $94 \mathrm{p}$.

*Berger, D.L., Ross, W.C., Thodal, C.E., and Robledo, A.R., 1997, Hydrogeology and simulated effects of urban development on water resources of Spanish Springs Valley, Washoe County, west-central Nevada: U.S. Geological Survey Water-Resources Investigations Report 96-4297, 80 p.

*Berger, D.L., and Medina, R.L., 1999, Spatial ground-water data base in Carson Valley, Douglas County, Nevada, and Alpine County, California-Development and documentation: U.S. Geological Survey Water-Resources Investigations Report 99-4188, 1 CD-ROM

*Berger, D.L., Maurer, D.K., Lopes, T.J., and Halford, K.J., 2004, Estimates of natural ground-water discharge and characterization of water quality in Dry Valley, Washoe County, West-Central Nevada, 2002-2003: U.S. Geological Survey Scientific Investigations Report 2004-5155, 46 p.

Blankennagel, R.K., and Weir, J.E., Jr., 1973, Geohydrology of the eastern part of Pahute Mesa, Nevada Test Site, Nevada: U.S. Geological Survey Professional Paper 712-B, 35 p.

Burbey, T.J., 1993, Shallow ground water in the Whitney Area, southeastern Las Vegas Valley, Clark County, Nevada—Part II, Assessment of a proposed strategy to reduce the contribution of salts to Las Vegas Wash: U.S. Geological Survey Water-Resources Investigations Report 92-4051, 58 p.

Burbey, T.J., 1995, Pumpage and water-level change in the principal aquifer system of Las Vegas Valley, Nevada, 1980-90: Nevada Division of Water Resources, Information Report 34, 224 p.
Burbey, T.J., 1997, Hydrogeology and potential for groundwater development, carbonate-rock aquifers, southern Nevada and southeastern California: U.S. Geological Survey Water-Resources Investigations Report 95-4168, 65 p.

Byers, F.M., Jr., and Hawkins, W.L., 1981, Geology of drill hole UE-18t and Area 18, Timber Mountain caldera moat, Nevada Test Site, with a section on geophysical logging by D.C. Muller: U.S. Geological Survey Report USGS-474312 [Special Studies I-097], 69 p.

Carlsen, C.L., Lunnis, R.C., and Prudic, D.E., 1991, Changes in water levels and water quality in shallow ground water, Pittman-Henderson Area, Clark County, Nevada, resulting from diversion of industrial cooling water from ditch to pipeline in 1985: U.S. Geological Survey Water-Resources Investigations Report 89-4093, 69 p.

Cohen, Philip, 1963, An evaluation of the water resources of the Humboldt River Valley near Winnemucca, Nevada: Nevada Department of Conservation and Natural Resources, Water Resources Bulletin 24, 103 p.

*Cohen, Philip, 1964, A brief appraisal of the ground-water resources of the Grass Valley area, Humboldt and Pershing Counties, Nevada: Nevada Department of Conservation and Natural Resources, Ground-Water Resources - Reconnaissance Report 29, 40 p.

*Cohen, Philip, 1964, Preliminary results of hydrologic investigations in the valley of the Humboldt River near Winnemucca, Nevada: Nevada Department of Conservation and Natural Resources, Water Resources Bulletin 22, 59 p.

*Cohen, Philip, and Everett, D.E., 1963, A brief appraisal of the ground-water hydrology of the Dixie-Fairview Valley area, Nevada: Nevada Department of Conservation and Natural Resources, Ground-Water Resources - Reconnaissance Report 23, $40 \mathrm{p}$.

Cohen, Philip, and Loeltz, O.J., 1964, Evaluation of hydrogeology and hydrogeochemistry of the Truckee Meadows area, Washoe County, Nevada: U.S. Geological Survey Water-Supply Paper 1779-S, 63 p.

Cooley, R.L, Spane, F.A., Jr., and Scheibach, R.B., 1974, Reno folio hydrologic map: Nevada Bureau of Mines and Geology, Environmental Series Reno Area.

Covay, K.J., Banks, J.M., Bevans, H.E., and Watkins, S.A., 1996, Environmental and hydrologic settings of the Las Vegas Valley area and the Carson and Truckee River Basins, Nevada and California: U.S. Geological Survey WaterResources Investigations Report 96-4087, 72 p.

Crosthwaite, E.G., 1963, Ground-water appraisal of Antelope and Middle Reese River Valleys, Lander County, Nevada: Nevada Department of Conservation and Natural Resources, Ground-Water Resources - Reconnaissance Report 19, 33 p. 
D'Agnese, F.A., Faunt, C.C., Turner, A.K., and Hill, M.C., 1997, Hydrogeologic evaluation and numerical simulation of the Death Valley regional ground-water flow system, Nevada and California: U.S. Geological Survey WaterResources Investigations Report 96-4300, 124 p.

Domenico, P.A., Stephenson, D.A., and Maxey, G.B., 1964, Ground water in Las Vegas Valley: Desert Research Institute, Technical Report no. 7, 53 p.

Doty, G.C., and Thordarson, William, 1983, Water table in rocks of Cenozoic and Paleozoic age, 1980, Yucca Flat, Nevada Test Site, Nevada: U.S. Geological Survey WaterResources Investigations Report 83-4067, 1 sheet, scale $1: 48,000$.

*Eakin, T.E., 1961, Ground-water appraisal of Long Valley, White Pine and Elko Counties, Nevada: Nevada Department of Conservation and Natural Resources, Ground-Water Resources - Reconnaissance Report 3, 35 p.

Eakin, T.E., 1962, Ground-water appraisal of Diamond Valley, Eureka and Elko Counties, Nevada: Nevada Department of Conservation and Natural Resources, Ground-Water Resources - Reconnaissance Report 6, 60 p.

*Eakin, T.E., and Lamke, R.D., 1966, Hydrologic reconnaissance of the Humboldt River Basin, Nevada: Nevada Department of Conservation and Natural Resources, Water Resources Bulletin 32, 107 p.

*Eakin, T.E., Hughes, J.L., and Moore, D.O., 1967, Waterresources appraisal of Steptoe Valley, White Pine and Elko Counties, Nevada: Nevada Department of Conservation and Natural Resources, Water Resources - Reconnaissance Report 42, 48 p.

Eakin, T.E., Maxey, G.B., and Robinson, T.W., 1951, Ground water in Goshute and Antelope Valleys, Elko County, Nevada, in Eakin, T.E., Maxey, G.B., Robinson, T.W., Fredricks, J.C., and Loeltz, O.J., Contributions to the hydrology of eastern Nevada: Nevada State Engineer, Water Resources Bulletin 12, p. 17-34.

Ervin, E.M., Luckey, R.R., and Burkhardt, D.J., 1994, Revised potentiometric-surface map, Yucca Mountain and vicinity, Nevada: U.S. Geological Survey Water-Resources Investigations Report 93-4000, 17 p.

*Everett, D.E., 1964, Ground-water appraisal of Edwards Creek Valley, Churchill County, Nevada: Nevada Department of Conservation and Natural Resources, Ground-Water Resources - Reconnaissance Report 26, 18 p.

Fridrich, C.J., Dudley, W.W., Jr., and Struckless, J.S., 1994, Hydrogeologic analysis of the saturated zone ground-water system under Yucca Mountain, Nevada: Journal of Hydrology, v. 154, p. 133-168.
Glancy, P.A., 1968, Water-resources appraisal of MesquiteIvanpah Valley area, Nevada and California: Nevada Division of Water Resources, Reconnaissance Report 46, 57 p.

Glancy, P.A., 1986, Geohydrology of the basalt and unconsolidated sedimentary aquifers in the Fallon area, Churchill County, Nevada: U.S. Geological Survey Water-Supply Paper 2263, 62 p.

*Hale, G.S., Trudeau, D.A., and Savard, C.S., 1995, Waterlevel data from wells and test holes through 1991 and potentiometric contours as of 1991 for Yucca Flat, Nevada Test Site, Nye County, Nevada: U.S. Geological Survey WaterResources Investigations Report 95-4177, scale 1:48,000.

*Handman, E.H., and Kilroy, K.C., 1997, Ground-water resources of northern Big Smoky Valley, Lander and Nye Counties, central Nevada: U.S. Geological Survey WaterResources Investigations Report 96-4311, 97 p.

*Handman, E.H., Londquist, C.J., and Maurer, D.K., 1990, Ground-water resources of Honey Lake Valley, Lassen County, California, and Washoe County, Nevada: U.S. Geological Survey Water-Resources Investigations Report 90-4050, 112 p.

*Harrill, J.R., 1968, Hydrologic response to irrigation pumping in Diamond Valley, Eureka and Elko Counties, Nevada, 1950-65, with a section on surface water by R.D. Lamke: Nevada Department of Conservation and Natural Resources, Water Resources Bulletin 35, 85 p.

*Harrill, J.R., 1969, Hydrologic response to irrigation pumping in Hualapai Flat, Washoe, Pershing, and Humboldt Counties, Nevada, 1960-67: Nevada Division of Water Resources, Bulletin 37, 75 p.

Harrill, J.R., 1970, Water-resources appraisal of the Granite Springs Valley area, Pershing, Churchill, and Lyon Counties, Nevada: Nevada Division of Water Resources, Reconnaissance Report 55, 36 p.

*Harrill, J.R., 1973, Evaluation of the water resources of Lemmon Valley, Washoe County, Nevada, with emphasis on effects of ground-water development to 1971: Nevada Division of Water Resources, Bulletin 42, $130 \mathrm{p}$.

Harrill, J.R., 1976, Pumping and ground-water storage depletion in Las Vegas Valley, Nevada, 1955-74: Nevada Division of Water Resources, Bulletin 44, $70 \mathrm{p}$.

Harrill, J.R., 1977, Hydrologic map, south Lake Tahoe quadrangle: Nevada Bureau of Mines and Geology Urban Map Series, Map 2Af, scale 1:24,000.

Harrill, J.R., 1986, Great Basin regional aquifer-system study, in Sun, R.J., ed., Regional aquifer-system analysis program of the U.S. Geological Survey-Summary of projects, 197884: U.S. Geological Survey Circular 1002, p. 146-151. 
Harrill, J.R., 1986, Ground-water storage depletion in Pahrump Valley, Nevada-California, 1962-75: U.S. Geological Survey Water-Supply Paper 2279, 53 p.

Harrill, J.R., and Katzer, Terry, 1980, General ground water, Las Vegas SE quadrangle: Nevada Bureau of Mines and Geology Urban Map Series, Map 3Af, scale 1:24,000.

Harrill, J.R., and Moore, D.O., 1970, Effects of ground-water development on the water regimen of Paradise Valley, Humboldt County, Nevada, 1948-68, and hydrologic reconnaissance of the tributary areas: Nevada Division of Water Resources, Bulletin 39, 123 p.

Harrill, J.R., and Preissler, A.M., 1994, Ground-water flow and simulated effects of development in Stagecoach Valley, a small, partly drained basin in Lyon and Storey Counties, western Nevada: U.S. Geological Survey Professional Paper 1409-H, 74 p.

Harrill, J.R., Welch, A.H., and Preissler, A.M., 1992, Hydrogeochemical evidence for subsurface inflow to Stagecoach Valley, Lyon County, Nevada, in Subitzky, Seymour, ed., Selected papers in the hydrologic sciences, 1988-92: U.S. Geological Survey Water-Supply Paper 2340, p. 179-193.

Herrera, N.B., Seiler, R.L., and Prudic, D.E., 2000, Conceptual evaluation of ground-water flow and simulated effects of changing irrigation practices on the shallow aquifer in the Fallon and Stillwater areas, Churchill County, Nevada: U.S. Geological Survey Water-Resources Investigations Report 99-4191, 70 p.

Hines, L.B., 1992, Quantification of natural ground-water evaporation in Smith Creek Valley, Lander County, Nevada, in Subitzky, Seymour, ed., Selected papers in the hydrologic sciences, 1988-92: U.S. Geological Survey Water-Supply Paper 2340, p. 9-20.

*Hood, J.W., and Rush, F.E., 1965, Water-resources appraisal of the Snake Valley area, Utah and Nevada: Nevada Department of Conservation and Natural Resources, Water Resources - Reconnaissance Report 34, 43 p.

*Huxel, C.J., Jr., and Harris, E.E., 1969, Water resources and development in Mason Valley, Lyon and Mineral Counties, Nevada, 1948-65: Nevada Division of Water Resources, Bulletin 38, $77 \mathrm{p}$.

*Huxel, C.J., Jr., Parkes, J.E., and Everett, D.E., 1966, Effects of irrigation development on the water supply of Quinn River Valley area, Nevada and Oregon, 1950-64: Nevada Department of Conservation and Natural Resources, Water Resources Bulletin 34, 80 p.

Katzer, Terry, 1980, General ground-water map, Carson City quadrangle: Nevada Bureau of Mines and Geology Urban Map Series, Carson City Folio, Map 1Af, scale 1:24,000.
Katzer, Terry, Harrill, J.R., Berggren, Gregg, and Plume, R.W., 1985, Ground-water map, Las Vegas SW quadrangle: Nevada Bureau of Mines and Geology Urban Map Series, Las Vegas SW Folio, Map 3Bf, scale 1:24,000.

Kilroy, K.C., 1991, Ground-water conditions in Amargosa Desert, Nevada-California, 1952-87: U.S. Geological Survey Water-Resources Investigations Report 89-4101, 93 p.

Laczniak, R.J., Cole, J.C., Sawyer, D.A., and Trudeau, D.A., 1996, Summary of hydrogeologic controls on ground-water flow at the Nevada Test Site, Nye County, Nevada: U.S. Geological Survey Water-Resources Investigations Report 96-4109, 59 p.

Lawrence, S.J., 1996, Nitrate and ammonia in shallow ground water, Carson City urban area, Nevada, 1989: U.S. Geological Survey Water-Resources Investigations Report 96-4224, $53 \mathrm{p}$.

Lico, M.S., 1992, Detailed study of irrigation drainage in and near wildlife management areas, west-central Nevada, 1987-90, Part A. Water quality, sediment composition, and hydrogeochemical processes in Stillwater and Fernley Wildlife Management Areas: U.S. Geological Survey WaterResources Investigations Report 92-4024-A, 65 p.

*Malmberg, G.T., 1961, A summary of the hydrology of the Las Vegas ground-water basin, Nevada, with special reference to the available supply: Nevada Department of Conservation and Natural Resources, Water Resources Bulletin $18,23 \mathrm{p}$.

*Malmberg, G.T., and Worts, G.F., Jr., 1966, The effects of pumping on the hydrology of Kings River Valley, Humboldt County, Nevada, 1957-64: Nevada Department of Conservation and Natural Resources, Water Resources Bulletin 31, $57 \mathrm{p}$.

Maurer, D.K., 1986, Geohydrology and simulated response to ground-water pumpage in Carson Valley, a river-dominated basin in Douglas County, Nevada, and Alpine County, California: U.S. Geological Survey Water-Resources Investigations Report 86-4328, 109 p.

Maurer, D.K., 1992, Hydrogeology of the Genoa quadrangle, Nevada: Nevada Bureau of Mines and Geology Urban Map Series, Genoa Folio, Map 1Cf, scale 1:24,000.

*Maurer, D.K., 1997, Hydrology and ground-water budgets of the Dayton Valley Hydrographic Area, west-central Nevada: U.S. Geological Survey Water-Resources Investigations Report 97-4123, 89 p.

Maurer, D.K., and Fischer, J.M., 1988, Recharge to the Eagle Valley ground-water basin by streamflow in Vicee Canyon, west-central Nevada: U.S. Geological Survey WaterResources Investigations Report 88-4158, 66 p. 
Maurer, D.K., and Moffatt, R.L., 1992, General hydrology of the Vista quadrangle [Nevada]: Nevada Bureau of Mines and Geology Urban Maps Series, Vista Folio, Map 4Hf, scale 1:24,000.

Maurer, D.K., and Peltz, L.A., 1994, Potential for, and possible effects of, artificial recharge in Carson Valley, Douglas County, Nevada: U.S. Geological Survey Water-Resources Investigations Report 94-4126, 4 sheets.

*Maurer, D.K., Plume, R.W., Thomas, J.M., and Johnson, A.K., 1996, Water resources and effects of changes in ground-water use along the Carlin Trend, north-central Nevada: U.S. Geological Survey Water-Resources Investigations Report 96-4134, 146 p.

Maxey, G.B., and Eakin, T.E., 1949, Ground water in White River Valley, White Pine, Nye, and Lincoln Counties, Nevada: Nevada State Engineer, Water Resources Bulletin $8,59 \mathrm{p}$.

Morgan, D.S., 1982, Hydrogeology of the Stillwater geothermal area, Churchill County, Nevada: U.S. Geological Survey Open-File Report 82-345, 95 p.

Morgan, D.S., and Dettinger, M.D., 1996, Ground-water conditions in Las Vegas Valley, Clark County, Nevada, Part II. Hydrogeology and simulation of ground-water flow: U.S. Geological Survey Water-Supply Paper 2320-B, 124 p.

Nowlin, J.O., 1982, Ground-water levels and water quality in an area near Topaz Lake, Douglas County, Nevada: U.S. Geological Survey Open-File Report 80-2046, 76 p.

O’Hagan, M.D., and Laczniak, R.L., 1996, Ground-water levels beneath eastern Pahute Mesa and vicinity, Nevada Test Site, Nye County, Nevada: U.S. Geological Survey WaterResources Investigations Report 96-4042, 1 sheet.

Olmsted, F.H., Glancy, P.A., Harrill, J.R., Rush, F.E., and Van Denburgh, A.S., 1975, Preliminary hydrogeologic appraisal of selected hydrothermal systems in northern and central Nevada: U.S. Geological Survey Open-File Report 75-56, $360 \mathrm{p}$.

Phoenix, D.A., 1948, Geology and ground water in the Meadow Valley Wash drainage area, above the vicinity of Caliente, Nevada: Nevada State Engineer, Water Resources Bulletin 7, $117 \mathrm{p}$.

Plume, R.W., 1985, Ground-water resources in Kyle and Lee Canyons, Spring Mountains, Clark County, Nevada: U.S. Geological Survey Open-File Report 84-438, 47 p.

Plume, R.W., 1995, Water resources and potential effects of ground-water development in Maggie, Marys, and Susie Creek Basins, Elko and Eureka Counties, Nevada: U.S. Geological Survey Water-Resources Investigations Report 94-4222, 87 p.
*Plume, R.W., and Ponce, D.A., 1999, Hydrogeologic framework and ground-water levels, 1982 and 1996, Middle Humboldt River Basin, north-central Nevada: U.S. Geological Survey Water-Resources Investigations Report 98-4209, 2 sheets.

*Prudic, D.E., and Herman, M.E., 1996, Ground-water flow and simulated effects of development in Paradise Valley, a basin tributary to the Humboldt River in Humboldt County, Nevada: U.S. Geological Survey Professional Paper 1409-F, $92 \mathrm{p}$.

Prudic, D.E., Harrill, J.R., and Burbey, T.J., 1995, Conceptual evaluation of regional ground-water flow in the carbonate-rock province of the Great Basin, Nevada, Utah, and adjacent States: U.S. Geological Survey Professional Paper 1409-D, 102 p.

Robison, J.H., 1984, Ground-water level data and preliminary potentiometric-surface maps, Yucca Mountain and vicinity, Nye County, Nevada: U.S. Geological Survey WaterResources Investigations Report 84-4197, 8 p.

*Rush, F.E., 1967, Water-resources appraisal of Washoe Valley, Nevada: Nevada Department of Conservation and Natural Resources, Water Resources - Reconnaissance Report 41, 39 p.

Rush, F.E., 1971, Regional ground-water systems in the Nevada Test Site area, Nye, Lincoln, and Clark Counties, Nevada: Nevada Division of Water Resources, Reconnaissance Report 54, 25 p.

*Rush, F.E., 1974, Static ground water levels of Nevada: Nevada Division of Water Resources map, scale 1:750,000, 1 sheet.

Rush, F.E., 1975, Hydrologic map, Washoe City quadrangle: Nevada Bureau of Mines and Geology Urban Maps Series, Washoe City Folio, Map 5Af, scale 1:24,000.

*Rush, F.E., and Eakin, T.E., 1963, Ground-water appraisal of Lake Valley in Lincoln and White Pine Counties, Nevada: Nevada Department of Conservation and Natural Resources, Ground-Water Resources - Reconnaissance Report 24, 29 p.

*Rush, F.E., and Katzer, T.L., 1973, Water-resources appraisal of Fish Lake Valley, Nevada and California: Nevada Division of Water Resources, Reconnaissance Report 58, 70 p.

*Rush, F.E., and Schroer, C.V., 1970, Water resources of Big Smoky Valley, Lander, Nye, and Esmeralda Counties, Nevada: Nevada Division of Water Resources, Bulletin 41, $84 \mathrm{p}$.

Rush, F.E., and Schroer, C.V., 1976, Geohydrology of Smith Valley, Nevada, with special reference to the water-use period 1953-72: Nevada Division of Water Resources, Bulletin $43,95 \mathrm{p}$. 
Schaefer, D.H., and Harrill, J.R., 1995, Simulated effects of proposed ground-water pumping in 17 basins of east-central and southern Nevada: U.S. Geological Survey WaterResources Investigations Report 95-4173, 71 p.

*Schaefer, D.H., and Whitney, Rita, 1992, Geological framework and ground-water conditions in basin-fill aquifers of the Dayton Valley and Churchill Valley hydrographic areas, western Nevada: U.S. Geological Survey Water-Resources Investigations Report 91-4072, 12 p.

*Seiler, R.L., and Allander, K.K., 1993, Water-level changes and directions of ground-water flow in the shallow aquifer, Fallon area, Churchill County, Nevada: U.S. Geological Survey Water-Resources Investigations Report 93-4118, $74 \mathrm{p}$.

*Sinclair, W.C., 1962, Ground-water resources of Pine Forest Valley, Humboldt County, Nevada: Nevada Department of Conservation and Natural Resources, Ground-Water Resources - Reconnaissance Report 4, 22 p.

*Sinclair, W.C., and Loeltz, O.J., 1963, Ground-water conditions in the Fernley-Wadsworth area, Churchill, Lyon, Storey, and Washoe Counties, Nevada: U.S. Geological Survey Water-Supply Paper 1619-AA, 22 p.

*Thomas, J.M., Carlton, S.M., and Hines, L.B., 1989, Groundwater hydrology and simulated effects of development in Smith Creek Valley, a hydrologically closed basin in Lander County, Nevada: U.S. Geological Survey Professional Paper 1409-E, 57 p.

Thomas, J.M., Mason, J.L., and Crabtree, J.D., 1986, Groundwater levels in the Great Basin region of Nevada, Utah, and adjacent states: U.S. Geological Survey Hydrologic Investigations Atlas HA-694-B, 2 sheets.

Thomas, J.M., Welch, A.H., and Dettinger, M.D., 1997, Geochemistry and isotope hydrology of representative aquifers in the Great Basin Region of Nevada, Utah, and adjacent states: U.S. Geological Survey Professional Paper 1409-C, $100 \mathrm{p}$.

Waddell, R.K., Robison, J.H., and Blankennagel, R.K., 1984, Hydrology of Yucca Mountain and vicinity, Nevada-California-Investigative results through mid-1983: U.S. Geological Survey Water-Resources Investigations Report 84-4267, $72 \mathrm{p}$.

*Walker, G.E., and Eakin, T.E., 1963, Geology and ground water of Amargosa Desert, Nevada-California: Nevada Department of Conservation and Natural Resources, Ground-Water Resources - Reconnaissance Report 14, 45 p.

Wilson, J.W., 2001, Potentiometric surface, carbonate-rock province, southern Nevada and southeastern California, 1998-2000: U.S. Geological Survey Open-File Report 01$335,15 \mathrm{p}$.
Winograd, I.J., and Thordarson, William, 1975, Hydrogeologic and hydrochemical framework, south-central Great Basin, Nevada-California, with special reference to the Nevada Test Site: U.S. Geological Survey Professional Paper 712-C, $126 \mathrm{p}$.

Worts, G.F., Jr., and Malmberg, G.T., 1966, Hydrologic appraisal of Eagle Valley, Ormsby County, Nevada: Nevada Department of Conservation and Natural Resources, Water Resources - Reconnaissance Report 39, 55 p.

Zones, C.P., 1961, Ground-water reconnaissance of Winnemucca Lake Valley, Pershing and Washoe Counties, Nevada: U.S. Geological Survey Water-Supply Paper 1539C, $18 \mathrm{p}$.

Zones, C.P., 1963, Ground water in the alluvium of Kings River Valley, Humboldt County, Nevada: U.S. Geological Survey Water-Supply Paper 1619-L, 38 p.

\section{Plates}

Plates are found in separate PDF files. Click on the desired link to view or download plate.

Plate 1. Map showing water-table contours in Nevada, 19472004.

Plate 2. Map showing water-table surfaces in Nevada, 19472004. (Lower resolution version here)

Plate 3. Map showing depth-to-water surfaces in Nevada, 1947-2004. (Lower resolution version here) 


\section{疍}

훙

를

움

更

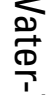

함

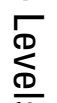

$\stackrel{\$}{2}$

음

今

产

z

ֻั)

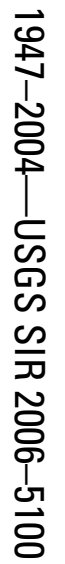

